This PDF is a selection from a published volume from the National Bureau of Economic Research

Volume Title: Challenges to Globalization: Analyzing the Economics

Volume Author/Editor: Robert E. Baldwin and L. Alan Winters, editors

Volume Publisher: University of Chicago Press

Volume ISBN: 0-262-03615-4

Volume URL: http://www.nber.org/books/bald04-1

Conference Date: May 24-25, 2002

Publication Date: February 2004

Title: Home- and Host-Country Effects of Foreign Direct Investment

Author: Robert E. Lipsey

URL: http://www.nber.org/chapters/c9543 


\title{
Home- and Host-Country Effects of Foreign Direct Investment
}

\author{
Robert E. Lipsey
}

\subsection{Introduction}

Protests against "globalization" involve a wide spectrum of discontents with modern life and market economies. They include the growth of international trade and specialization, and the disruptions of traditional or established economic practices they entail. They include also the actions of intergovernmental agencies, such as the International Trade Organization (ITO), International Monetary Fund (IMF), the World Bank, and the regional development banks. And it is rare that multinational firms are not mentioned, as the presumed leaders and chief beneficiaries of globalization.

There are also more specific accusations against multinationals. Many evils are alleged. They depress wages and employment at home by moving production abroad. They depress wages in their host countries by exploiting helpless workers. They stifle host-country growth by displacing local firms and obstructing their technological progress. Anyone who believes that these fears are a new phenomenon should read the chapter on "The Reactions to Foreign Investment" in Wilkins (1989, chap. 16), where the author describes how "in the mid-1880s and into the 1890s, a passionate, hitherto unmatched fury mounted against foreign investment in the United States" (566).

Robert E. Lipsey is professor emeritus of economics at Queens College and the Graduate Center, City University of New York, and a research associate and director of the New York office of the National Bureau of Economic Research (NBER).

I am indebted to Li Xu for help in searching for, assembling, and reviewing the many papers discussed here. Robert E. Baldwin, of the University of Wisconsin; Andrew Bernard, of Yale University; Vanessa Strauss-Kahn, of INSEAD; and Birgitta Swedenborg, of the Center for Business and Policy Studies, Stockholm, made helpful comments on earlier versions of this paper. 
To the extent that opposition to globalization stems from different values that view as bad traditional economic goods such as higher consumption or the growth of production and exchange, I do not attempt to deal with them. Many of the other accusations are framed in vague terms. I attempt to appraise them by classifying the effects of multinational operations under several homogeneous headings and reviewing what research has concluded with respect to each topic. On home-country effects, I summarize the findings on home-country exports and home-country factor demand. On host-country effects, I discuss wages, productivity, exports, the introduction of new industries, and the rate of economic growth.

There are two concepts of foreign direct investment (FDI) and two matching ways of measuring it. One is that FDI is a particular form of the flow of capital across international boundaries. It gives rise to a particular form of international assets for the home countries, specifically, the value of holdings in entities, typically corporations, controlled by a home-country resident or in which a home-country resident holds a certain share of the voting rights. The other concept of direct investment is that it is a set of economic activities or operations carried out in a host country by firms controlled or partly controlled by firms in some other (home) country. These activities are, for example, production, employment, sales, the purchase and use of intermediate goods and fixed capital, and the carrying out of research.

The former of these two concepts is the one reflected in balance-ofpayments accounts. The measures of it, flows and stocks of direct investment, are the only virtually ubiquitous quantitative indicators of FDI. However, if the effects of FDI stem from the activity of the foreign-owned firms in their host countries, the balance-of-payments measures have many defects for any examination of these impacts. The activity is frequently not in the same industry as the stock, or not in the same host country, or has not originated from the same home country (Lipsey 2003; United Nations 2001). For this reason, wherever possible, I emphasize studies based on activity, such as production or employment, rather than those based on balance-of-payments stocks and flows.

\subsection{What Happens When a Foreign Direct Investment Is Made?}

Much of the earlier economics literature on FDI, but not the business literature, treated it as a part of the general theory of international capital movements, based on differences among countries in the abundance and cost of capital. If country A makes a direct investment in country B, there is an addition to the physical capital of country $\mathrm{B}$, and new production capacity is created there. The investing firm in A will have chosen to use some of its capital in B instead of in A. If the output is tradable, some production that now takes place in country B may replace production that formerly took place in country A. The investing firm may have reduced its 
production in its home country, A, possibly by shutting down or selling a plant, and opened up a new plant abroad to serve the same market.

A different possibility is that when a firm in country A makes a direct investment in country $\mathrm{B}$, the stock of physical capital and the level of production are unchanged in both countries. Country A owners and managers in industry $\mathrm{X}$, using the skills they have acquired in home production, buy out country B owners with lower skills in that industry and operate the industry X plants in country B more efficiently than before. Country B owners use their capital, released by the buyout, in other industries. They might, for instance, lend it to other owners and managers in country B, skilled in industry $\mathrm{Y}$, to enable them to buy out less competent owners in that industry in country A. No net movement of physical or financial capital is necessarily implied, although it could take place.

This latter picture belongs to what Markusen (1997) and Markusen and Maskus (2001) have called the "knowledge-capital model" of the multinational enterprise. It is related also to what Caves (1996, chap. 1) refers to as the dependence of multinational enterprises on "proprietary assets," or "firm-specific" assets. And it also fits with Romer's distinction (1993a,b) between the roles in economic development of what he calls "ideas" in contrast to "objects." Caves (1996) traces the decline of the view that multinationals are principally arbitrageurs of financial or physical capital to Hymer (1960) and to Kindleberger (1969), who adopted many of Hymer's ideas. Dunning $(1970,321)$ summarized their view as being that "the modern multi-national company is primarily a vehicle for the transfer of entrepreneurial talent rather than financial resources."

The capital-flow story depends on the advantages of countries as locations for production, and changes in such advantages. The entrepreneurship story, on the other hand, hinges on characteristics of firms and their managers, rather than those of countries. Capital flows imply changes in the industrial composition of production and employment in home and host countries. In industries producing tradables, they imply shifts in the composition of exports and imports. Entrepreneurship explanations contain implications for the ownership of production, but not necessarily for the location of production.

It is desirable to distinguish the location choices within firms from the location choices for industries in the aggregate. If, for example, because of a decline in communication costs, or an increase in the severity of currency fluctuations, firms in all countries decided to diversify their production locations, each firm in each country might shift production from home to foreign locations through FDI. However, there might be no change in the geographical location of production as a whole, because in each country, the outward shift of home-country firms' production might be balanced by the inward shift of foreign firms' production. Or there could be a general shift of production toward markets in each industry. 
If there is a geographical relocation of production, the force behind it might be a change in factor prices, such as a rise in the home-country price of labor, or a rise in the home-country price of a natural resource. In that case, we would expect a shift in the production of labor-intensive or resource-intensive goods away from the home country, both within firms and in the aggregate. That might be reflected in a decline in firm and homecountry exports, but it might also be the case that it was the decline of home-country exports, or the expectation of such a decline, that precipitated the production shift. It is difficult to distinguish between trade shifts produced by exogenous production-location decisions and location shifts produced by exogenous shifts, or potential shifts in trade. The difficulty of that distinction has haunted most analyses of home-country impacts.

There is some indication that the exchange of ownership has become a larger part of FDI flows over time and particularly during the 1990s. One piece of evidence is that the value of mergers and acquisitions has risen relative to the value of FDI flows and relative to world output (United Nations [UN] 2000, chap. 4). Most of this merger and acquisition activity has taken place among the developed countries. The rising trend seems to reflect an increase in mergers and acquisitions in general, rather than one mainly in international, or cross-border, ones: the international share appears to have been relatively constant since the late 1980s (UN 107). Much of this activity has taken the form of exchanges of stock, where relatively little net capital flow is involved.

There are important policy issues behind the strong interest in effects of the internationalization of production. Should countries promote or discourage the internationalization of their home-country firms, or should policy be neutral? Should countries encourage the entrance of foreign producers, or discourage it, or leave the decisions to market forces? Some of the early studies of U.S. direct investment abroad were motivated by the belief that features of the U.S. taxation of corporations were important inducements to foreign investment. That question may not have been settled, but the spread of the practice of internationalization from firms based in the United States to those from many other countries suggests that there were forces beyond any distortionary U.S. tax policies that were driving these trends.

\subsection{Home-Country Effects of Outward Foreign Direct Investment}

\subsubsection{Outward Foreign Direct Investment and Home-Country Exports}

Since the United States was the dominant outward direct investor in the period after World War II, much of the debate about the home-country consequences of FDI took place first there. The debate over the possible substitution of U.S. firms' foreign production for U.S. exports was most intense during the time of worries about the balance of payments during the 
1960s. Curiously, earlier studies of U.S. foreign investment, such as Lewis (1938) and Madden, Nadler, and Sauvain (1937), did not take up the export substitution issue, despite the high unemployment levels of the 1930s. In the 1960s, there was a campaign against outward investment, largely fueled by fears about effects on U.S. exports and, presumably, domestic employment, that was supported by labor unions and culminated in the unsuccessful attempt to pass the Burke-Hartke bill.

The controversies of this period spawned a series of studies relating outward FDI to home-country exports. There are a number of different questions that can be asked, and they have not always been clearly distinguished, although the implications of the answers to them differ considerably. One set of questions is about the relationships within the individual investing firm. One is about the relation, for an individual parent firm, between its production in a host country and its exports to that country. A second is about the relation of a firm's production in a country to its exports to the world, taking account of the possibility that affiliate exports to other countries might affect parent markets there. A third is about the relation between a firm's production in all foreign countries and its exports to the world, taking account of all interrelationships between production abroad and exports. All of these are issues of firm strategy: how a firm chooses to serve markets around the world. There are no necessary inferences to be drawn about effects on the firm's home country as a whole, without knowledge about how other firms in the home country or other countries respond or react to the same stimuli.

A second set of questions is about the relation of the aggregate of decisions by a country's firms about production abroad to home-country exports in the same industry or in the aggregate, or to a home-country or industry employment or employment of different types of labor. These aggregate decisions incorporate the reactions of one firm in a country to the actions of other firms.

A third set of questions is about the relation between the decisions on the location of production made by firms from all countries on the worldwide pattern of production, trade, and employment, or on any particular countries' position. One reason these questions are rarely asked is that little is known about the outward FDI activities of about half or more of the world's direct investors, because most countries do not inquire into what their firms do outside their countries' borders.

The basic problem with studies of these questions has always been the close connection between the factors that determine a firm's exports and those that determine its foreign direct investment. A country's most competent and successful firms tend to export and to invest in production abroad, and the same is generally true of the most successful industries. All the research indicates an awareness of the problem, and the studies attempt to deal with it, usually in ways found unsatisfactory by critics.

The most common type of study was of the first question described 
above. Exports by a firm or an aggregate of firms in an industry to a foreign market were related to the firm's investment or production or employment in that market. The interrelations between exports and investment could be dealt with by assumption, as in the case of the Reddaway reports, that in the absence of a British-owned plant in a market, the alternative was a foreign-owned plant of the same size in the same industry (Reddaway et al. 1967, Reddaway, Potter, and Taylor 1968). That assumption essentially guaranteed a positive, or complementary, relationship between a firm's exports and its foreign production. In the other direction, Bergsten, Horst, and Moran $(1978,98)$ described the assumptions in Frank and Freeman (1975), and some in Hufbauer and Adler (1968), as assuming “. . . that foreign investment can only displace U.S. exports." Their own analysis of the first set of questions, based on U.S. aggregate data, cautiously summarized, pointed to mainly complementary relationships (Bergsten, Horst, and Moran 1978, 93-96). The studies by Lipsey and Weiss (1981, 1984), the first of exports, by industry, to individual destinations, and the second of total exports by individual U.S. firms, concluded that exports and production abroad by U.S. firms were, for the most part, complementary. A study using a later U.S. census of direct investment abroad found more mixed results for effects on total U.S. exports, mostly no relation, but where there was a significant relation, more frequently positive than negative (Blomström, Lipsey, and Kuchycky 1988).

Two of the few studies based on access to the confidential individual firm data collected by the U.S. Department of Commerce were Brainard (1997) and Brainard and Riker (1997). The focus of the Brainard and Riker study was on employment, rather than exports, but it is relevant here because employment issues lie behind much of the interest in exports. A feature of these studies, in contrast to many earlier ones of the United States and Sweden, is a more standard definition of complementarity and substitution, relating employment changes to wage changes in various locations. The limitation of this definition of complementarity is that it excludes home-country responses to variables other than the price of labor. These might include income growth, trade restrictions, policies toward direct investment, or changes in nonlabor costs of producing outside the home country. Brainard and Riker concluded that while there is some competition between a manufacturing firm's employment at home and that abroad, the degree of substitution is low. Mostly, competition takes place among workers in affiliates in different developing countries. Brainard (1997), testing the importance of factor price differences as an explanation for the location of foreign operations, dismisses it in favor of explanations based on the advantages of proximity to markets, among other factors. She suggests that "the overall complementarity between trade and affiliate sales" is attributable to the fact that both "are increasing in market size and intellectual property advantages..." (539). 
A study along similar lines for Swedish firms based on individual firm data, Braconier and Ekholm (2000), produced different results. There was evidence of "a substitutionary relationship between parent employment in Sweden and affiliate employment in other high-income locations" but no "evidence of a relationship in either direction between parent firm employment and affiliate employment in low-income locations" (459).

Concerns in Sweden about home-country effects of FDI led to a series of studies by Swedenborg (1973, 1979, 1982, 1985, 2001), and by Swedenborg, Johansson-Grahn, and Kinnwall (1988). An important and innovative feature of Swedenborg (1979) was the use of two-stage least squares to attempt to deal with the endogeneity of exports and the mutual determination with investment. That procedure was carried into her later work as well. The latest of her papers (Swedenborg 2001), in addition, takes advantage of the longitudinal aspect of the Swedish data to examine the effects on firm exports of changes in a firm's foreign production over time. She concludes that "the enormous growth of foreign production by Swedish firms in the thirty-year period, 1965-94 has not, in itself, had a negative effect on parent-company exports" (121). These studies examine parent-company exports to individual countries as well as total parent exports. Blomström, Lipsey, and Kuchycky (1988, 268-69), using total Swedish exports and changes in them, rather than parent exports as the dependent variables, found mainly positive relationships with production abroad and its growth.

As data on Japanese multinationals have become available for research in recent years, similar calculations have been carried out, with both parent exports (Lipsey, Ramstetter, and Blomström 2003) and Japanese industry exports (Lipsey and Ramstetter 2003) as dependent variables. In the minority of industries where any relationship between exports and overseas production can be discerned, the relation was positive, as in the United States and Sweden. The relationships for the three countries are compared and summarized in Lipsey, Ramstetter, and Blomström (2000).

With the rise in unemployment levels in Europe and the increase in outward FDI by European firms, the possible connection between the two has become a popular subject for study in Europe. In a study of bilateral trade and direct investment relationships for France, Fontagné and Pajot (2002) found complementarity between investment flows and net exports both for countries as a whole and for individual industries, and concluded that much of the complementarity between countries came from spillovers among industries. Studies by Chédor and Mucchielli (1998) and by Chédor, Mucchielli, and Soubaya (2002), the latter based on panel data for individual French firms and the former concerned with effects of developed countries' direct investment in developing countries, both produced conclusions that investment and home-country exports were complementary.

A recent survey of Australian firms' investment overseas concluded that 
"outward direct investment by Australian firms is mainly tapping into new growth and market opportunities for firms, rather than substituting for, or displacing, operations in Australia" (Australia Productivity Commission 2002, 24). The questions about effects on employment and production in Australia both produced more than 70 percent "no change" answers, but of those who reported changes increases were more common than decreases. The question on effects on exports from Australia also yielded a majority of "no change," but of those who reported an effect, the overwhelming majority reported an increase (25).

There have been many studies for other countries, mostly examining the relation of firms' or industries' foreign production to firm or industry exports. While there are some examples of negative associations, they are not frequent, and positive associations are more common. What is noticeable in a review of past studies, but is not commented on so often, is the frequency of results indicating no association in either direction. The elements of gravity equations are consistently significant in the expected direction, while the influence of FDI production is spotty and varies among host countries, industries, and types of parent-company exports. Bergsten, Horst, and Moran (1978) refer to the relationship as "haphazard" (97) and to "the presence of complementary and substitutional relations" (98). Lipsey and Weiss (1984) found mostly complementarity, but in half the industries there were no significant relationships at all. Blomström, Lipsey, and Kulchycky $(1988,275)$ reported that "[t]he predominant relationship between production in a country by affiliates of Swedish and U.S. firms and exports to that country from Sweden and the United States is something between neutrality and complementarity." Swedenborg, in her latest paper, concludes that ". . . the net effect of foreign production is probably close to zero" $(2001,117)$.

One way of interpreting these findings is that there are no universal relationships between production abroad by a firm or a country's firms and exports by the investing firms, their industries, and the country as a whole. There are circumstances in which foreign production tends to add to exports and circumstances in which it tends to reduce exports. The effect may depend on whether the foreign operations' relation to home operations is "horizontal" or "vertical," a distinction stressed by Markusen and Maskus (2001). It may also depend on the extent to which the foreign operations are in goods production or in service activities, are in developed or developing countries, or are in industries with plant-level or firm-level economies of scale.

It seems plausible that horizontal FDI should tend to substitute for parent exports, at least in manufacturing, if not in services, and that vertical FDI might tend to add to parent exports. But there is not much evidence for this conjecture. It is difficult to classify actual foreign operations into these theoretically neat categories. A firm's foreign operations usually in- 
clude some activities similar to those of the parent, but the industry identifications in most data do not distinguish among segments of an industry. The foreign operation may omit some parent activities, because they are performed for the affiliate by the parent. And the foreign operation may include some activities that are not performed by the parent, because they are provided by the home country's infrastructure or by a network of outside suppliers that does not exist in the host country. This distinction between horizontal and vertical FDI is more useful for thinking about multinational behavior or constructing models of it than for empirical research.

A problem with most studies of effects of FDI on home-country exports is that the terms "substitution" and "complementarity" are not clearly defined. That is partly because no policy measures are specified as determining the changes in investment or production. It is rare to find a clear counterfactual to which the existing situation is being compared.

The problem is illustrated by the example of a host-country tariff on imports that leads to both a reduction or cessation of imports and the establishment of host-country production owned by the former exporters. Higher local production is accompanied by reduced exports, an apparent case of substitution. The implied counterfactual is the original level of exports. In fact, the alternative to the establishment or expansion of hostcountry production may have been no exports and no sales by the parent firm or its country. That counterfactual would lead to the conclusion that the production and trade were either not related or were complementary, instead of the apparent substitution that appears in the data.

A possible interpretation of these studies is that foreign production by a firm or industry has very little influence on exports from the parent firm or its home country. Mainly, trade is determined by other factors, such as countries' changing comparative advantages in production. Direct investment is mainly about the ownership of production, not its location. What moves from country to country when a direct investment takes place is not primarily physical capital or production capacity, but rather intellectual capital, or techniques of production, unobserved and unmeasured. There may be movements of physical or financial capital accompanying the intellectual capital, but there need not be, and they are not the essence of the investment.

\subsubsection{Foreign Direct Investment and Home-Country Factor Demand}

Even if direct investment did not affect the location of total production and had no effect on a home country's exports, it could influence homecountry factor demand and factor prices through changes in the allocation of types of production within the firm. For example, multinationals based in rich countries might allocate their more labor-intensive production to their affiliates in poor countries, while concentrating their more capitalintensive or skill-intensive operations at home. Large differences in capital 
intensity between U.S. (home) operations and affiliates in developing countries were noted in Lipsey, Kravis, and Roldan (1982), but the response of capital intensity to labor costs was tested only among affiliates. If multinationals tended to allocate their production in this way, larger affiliate output relative to parent output should be associated with lower labor intensity and higher skill intensity in home production. In a study based on 1982 data, that relationship for labor intensity, measured by numbers of workers per unit of output, was found fairly consistently among industries in Kravis and Lipsey (1988), and less consistently for skill intensity, as measured by hourly wages. A similar calculation based on 1988 data (Lipsey 1995) found the same negative relation between affiliate net sales and parent employment, given the level of parent output. When affiliate activity was divided between manufacturing and nonmanufacturing operations, it was the manufacturing operations that accounted for the negative relation to parent employment; higher net sales by nonmanufacturing affiliates were associated with higher parent employment, given the level of parent output. In a later study covering the United States and Sweden, Blomström, Fors, and Lipsey (1997) found that larger production in developing countries by a U.S. firm was associated with lower labor intensity at home. In a further analysis of these data, Lipsey (2002) found that the effects on parent factor use across all types of countries were concentrated in the machinery and transport-equipment industries. There were positive effects on parent employment per unit of output in the machinery sectors and negative effects in transport equipment.

Swedish firms tended to use more labor per unit of output at home if they produced more abroad. That might be because production abroad required supervisory and other auxiliary employment at home. Or it might be that only the existence of foreign production enabled firms in a small market such as Sweden to develop and support extensive headquarters and research services. One explanation offered for the difference between Swedish and U.S. firms was that the Swedish investments in developing countries were concentrated in import substitution activities, and the affiliates exported little of their output, much less than U.S. affiliates. The Swedish affiliates could not, therefore, be woven into a worldwide division of labor that took account of factor price differences.

A later paper added Japanese firms to these comparisons (Lipsey, Ramstetter, and Blomström 2000). As in Swedish firms, higher levels of foreign output, given the level of home output, led to higher employment at home per unit of home output, presumably for supervision. It was suggested that Japanese firms could not easily shed redundant home-country workers even if they had wished to do so.

No explicit home-country production functions were fitted in these studies. Therefore, the variable for affiliate output incorporated the influ- 
ence of any home-country firm characteristics that were associated with the size of affiliate production. Furthermore, most of these results are from cross-sections. A different approach is taken by Slaughter (2000), examining what he refers to as "MNE [multinational enterprise] transfer," the shift, in percentage terms, of activities from parents to their foreign affiliates. He asks whether such "transfer" causes "skill upgrading," increases in the share of nonproduction worker wages in industry total wage bills, in the corresponding domestic U.S. industries.

Slaughter fits translog cost functions to data on the share of nonproduction worker wages in the total wage bills of thirty-two U.S. manufacturing industries, taking account of relative wage rates for production and nonproduction workers, capital-labor ratios, and output. Various measures of MNE transfer are added to these equations. All the transfer measures are based on ratios of affiliate activity in U.S. MNEs to total activity in the United States in the industries of the affiliates. The expectation of an effect on total industry skill levels is based on the fact that the parents of the affiliates account for most of their respective industries.

While higher investment in plant and equipment and higher industry output both led to skill upgrading, increases in affiliate activity in host countries had no significant impact. Slaughter $(2000,467)$ concludes that his finding "is inconsistent with models of MNEs in which affiliate activities substitute for parent unskilled-labor-intensive activities." That conclusion is reached despite the fact that there are no data for parent, rather than industry, skill levels, and that the MNE transfer measure is not specific to transfers to low-wage countries.

A different conclusion is reached by Head and Ries (2002) for the foreign operations of Japanese firms. Their calculations on an industry basis, similar to those of Slaughter (2000) for the United States, match his findings. The ratio of affiliate employment to the total of home and affiliate employment in an industry does not significantly affect the share of nonproduction worker wages in the total wage bill in the home country. However, once they move to a firm-level analysis, they do find that a higher affiliate employment share in the multinational firm produces a higher nonproduction worker wage share in the parent firm. That positive effect is associated with affiliate employment in low-wage countries; more employment in the United States appears to have the opposite effect. Thus, overseas production in low-wage countries seems to raise the parent firm's demand for skilled workers at home relative to the demand for unskilled workers.

The contrast between industry- and firm-level results suggests the possibility that substitution among types of activities may take place not only between home and foreign operations of a firm, but also between parent firms and nonmultinational firms in the same industry at home. That is a subject that has received very little attention, but deserves investigation. 


\subsubsection{Home-Country Exports and Home-Country Multinationals' Exports}

The idea that firms have comparative advantages separate from those of their home countries has been illustrated by several episodes. One is the contrast between the export shares of the United States and of U.S.-based multinational firms. During the period from 1966 to 1987, the U.S. share of world exports of manufactured goods fell from 17 percent to about 11 percent, a decline of a third. Over that same period, U.S.-based multinational firms' share of these exports, from the parent companies and their overseas affiliates combined, was quite stable, ending up in 1987 about where it began in 1966. The way this stability was achieved was that, as the world share of exports by the parent firms fell, the share of the overseas affiliates of these companies, exporting from their host countries, grew. The U.S. multinationals retained their shares of world exports, while the United States as a country was losing a large part of its share, because the multinationals' share depended on their firm-specific advantages, and the multinationals could exploit their firm-specific advantages by producing in other countries (Lipsey 1995, 12-13).

The divergence between home countries and home-country firms was not confined to the United States. For example, as Japanese export shares fell after the currency revaluations in 1985, Japanese affiliate export shares increased enough to approximately offset the decline in the country's share. Swedish shares in world manufactured exports fell by almost a third between 1965 and 1990, but Swedish multinationals' shares of world exports remained stable, or even increased a little (Lipsey 1995, 14-15).

For all these countries' multinationals, foreign production was apparently not only a way of exploiting their firm-specific assets in foreign markets, but also a way of protecting these market shares against unfavorable home-country developments. These might be exchange rate appreciations, increases in home-country wage levels, increases in taxes, or other changes that reduced the geographical advantages of their home countries as locations for production.

\subsection{Host-Country Effects of Inward Foreign Direct Investment}

\subsubsection{Host-Country Wages}

There are several ways in which the entrance or existence of foreign firms might affect wages in the host countries where they operate. One is if these firms offer higher wages than are paid by domestic firms. That possibility raises the question, dealt with in the next subsection, of whether they do pay higher wages. Even if they did pay higher wages, there might be no overall impact on wage levels if the higher wages simply reflected the selec- 
tion by foreign firms among workers, plants, or locations. They might select superior workers who would command high wages from any employer, or acquire higher-wage plants or firms, or concentrate their activities in high-wage industries or regions of a country. Thus, the second question is whether the payment of higher wages by foreign-owned firms results in higher wages in domestically owned firms, or "wage spillovers." The third question which I think is the most important from a policy point of view, is whether the activities of foreign-owned firms cause wages in general to be higher, on average, where they operate. That could be the result of the combination of higher wages in the foreign-owned plants and wage spillovers to domestically owned plants, but it could result from higher wages paid by foreign-owned firms even if there were no wage spillovers, or there were negative spillovers, to domestically owned plants. It could also occur without any wage differential between foreign-owned and domestically owned operations if labor markets were sufficiently competitive and the rise in demand for labor from foreign-owned operations forced all firms to raise their wage levels equally.

The measurement of wage levels is in some ways simpler than the measurement of productivity levels, taken up in section 9.4.2. It has its own problems, however. Most of the data are calculated as compensation/number of workers. Very few take account of hours of work, probably most important outside manufacturing but a possible source of mismeasurement in all industries. Probably more important is that there are few sources of data that contain information on the characteristics of workers, so that is impossible in most cases to distinguish between differences in wage rates for identical workers and differences in labor quality.

\section{Wage Comparisons}

It is rare to find a study of FDI and wages in any host country that does not find that foreign-owned firms pay higher wages, on average, than at least privately owned local firms. That is the case not only in developing countries, where most of the research has taken place, but also in developed, high-wage countries. To some extent, the differential can be explained by the industry composition of FDI, weighted toward relatively high-wage industry sectors. However, the differential exists within industries, in most industries in most countries.

There are two broad types of questions that can be asked about this phenomenon. One is about how labor markets operate in these host countries, particularly whether foreign firms pay higher prices for labor, in the sense of paying higher wages for workers of the same quality. The other is about how inward FDI affects labor markets, whether or not the effects can be accounted for by firm size, industry, capital intensity, research and development (R\&D) intensity, or other characteristics associated with foreign firms, that could belong to domestic firms as well as to foreign firms. 
Why would a foreign-owned firm pay a higher price than a domestic firm for labor of a given quality? It presumably could pay more than a domestically owned firm of the same size if its superior technology produced higher marginal labor productivity, but the expected response would be to expand output rather than to raise wages. Several reasons have been suggested. One is that it may be forced to do so by host-country regulations or home-country pressures. The Findlay model assumes that foreign firms pay a higher wage for labor of the same quality "for purposes of good public relations" $(1978,9)$. It might be that workers prefer locally owned firms, and must be compensated to overcome this preference. A third possibility is that foreign-owned firms pay a premium to reduce worker turnover, because they have brought some proprietary technology and wish to reduce the speed with which it leaks out to domestic rivals as employees change jobs. A fourth is that foreign firms, because of their limited understanding of local labor markets, pay higher wages to attract better workers, while more knowledgeable local firms can identify and attract better workers without paying them higher wages.

Studies attempting to measure the pure effect of foreignness are akin to successive distillations to remove impurities. The impurities in this case are explanations for differentials that are not necessarily intrinsic to foreignness, although they may be associated with it in practice. What may be more relevant to judging the optimum policies toward inward direct investment are studies with not quite as many controls. A state or a region or a country that wishes to estimate the effect of allowing inward FDI where it had been prohibited, or reducing obstacles to it, may not care why the foreign firm will pay higher wages. It is not relevant whether it is because the firm is foreign, because it is large, or because it brings more capitalintensive or skill-intensive production methods or better access to world markets. A domestic firm with the same attributes might have the same impact, but there may not be any such domestic firm, or if there is one, it may not be willing to make this particular investment.

If foreign firms are found to pay higher wages than local firms, for whatever reason, there are still several questions to be asked about the impact. If foreign firms hired high-wage workers away from local firms, or acquired local firms with skilled labor forces, we might find that foreign ownership was associated with higher wages in the foreign-owned firms and lower wages in domestic firms, but no difference in average industry wage levels. If foreign firms paid more, but did not differentially poach the best workers from local firms, one should find a larger presence of foreign ownership associated with higher wages in the industry, but not in locally owned firms in the industry. Or finally, we might find examples of "spillover," where higher foreign presence was associated with higher wages in domestically owned establishments.

Data on wage differences come in several different forms. Some are 
simple comparisons of average wages, or average wages by industry, where wage differences reflect any effects of firm or plant characteristics, such as size or capital intensity, and of worker characteristics, such as age and education. Others adjust for differences in plant characteristics, asking whether foreign-owned plants pay wages different from those in otherwise identical domestically owned plants. A third type, less common, adjusts for differences in worker characteristics, asking whether foreign-owned plants pay different wages from those in domestically owned plants for identical workers. And a fourth type, still more rare, adjusts for both plant and worker characteristics, asking whether foreign-owned plants pay different wages from those in identical domestically owned plants for identical workers.

Observations of higher wages in foreign-owned firms in developing countries go back a long time, although the earliest ones were not the result of careful statistical studies. An early study of American firms in Colombia concluded that "Colombian labor, whenever it is paid a stipulated wage, is better remunerated and granted more sanitary living quarters by foreigners than by natives, but the foreigners probably exact more systematic and strenuous effort" (Rippy 1931, 190). Another partial explanation for the higher wages was that "the American companies are eager to attract the most efficient labor" (Rippy, 191).

A study by Blomström (1983) of Mexican manufacturing industries in 1970 found that foreign-owned firms paid wages about 25 percent above those in domestically owned firms in manufacturing as a whole. Foreign firms' wage levels were also higher in each of four major groups of manufacturing industries, by 25 to 30 percent, except in capital goods industries, where the difference was much smaller (18-19).

Many of the recent studies of wages in foreign plants in developing countries have been based on manufacturing-sector data on individual establishments collected in national surveys and assembled by the World Bank. A number of them were carried out by Ann Harrison, in collaboration with several others, and wage data for three of these studies are summarized in Harrison (1996). There were statistically significant differences between wages in foreign-owned and domestically owned plants in three out of twelve industries in Côte d'Ivoire, twelve out of eighteen in Morocco, and eight out of nine in Venezuela. Ratios of foreign to domestic plant wages, where the differences were significant, ranged from 1.1 to 1.9 in Côte d'Ivoire, 1.3 to 2.6 in Morocco, and 1.2 to 2.0 in Venezuela. These are simple differences without adjustment for plant or worker characteristics. One problem with cross-sectional analyses of wage differences is the unknown role of unmeasured aspects of plant heterogeneity. For Venezuela, that problem could be dealt with by examining wages in individual plants over time. While the relationship between wages and foreign ownership of a plant was weaker, and the differential smaller than in aggregated data, 
foreign ownership of a plant, controlling for plant size, industry, and capital intensity, resulted in wages higher by $16-18$ percent (Aitken, Harrison, and Lipsey 1996, 368).

A paper on Morocco by Haddad and Harrison (1993) found that wages were 70 percent higher, on average, in foreign firms (58). The difference partly reflected the greater size of the foreign-owned firms; in weighted means, calculated to eliminate the size effect, the difference was reduced to 30 percent. The weighted average mean real wages were significantly higher in foreign-owned firms in sixteen out of eighteen individual industries. All the industries in which the wage differences were statistically significant showed higher wages in the foreign-owned plants. Something of an oddity, which casts some suspicion on the productivity measures discussed later, is that these higher wages in foreign-owned plants were accompanied by lower output per worker, at least in the weighted averages, and lower total factor productivity.

Several studies of Indonesia, such as Hill (1990) and Manning (1998), found that foreign firms paid higher wages than domestic firms. A recent paper using establishment data for Indonesia (Lipsey and Sjöholm 2003) found that in 1996, foreign-owned firms paid about 50 percent higher wages than private domestically owned firms in manufacturing as a whole, for both blue-collar and white-collar workers. When account was taken of the education levels of the workers, and of the industry and location of plants, foreign ownership was associated with wages about 25 percent higher for blue-collar workers and 50 percent higher for white-collar workers. Much of the differential was associated with the larger size of foreignowned plants and greater inputs of energy and other intermediate product. The authors concluded that there was strong evidence that foreign firms "paid a higher price for labor than domestically-owned plants" (13). They paid a higher price, by a large margin, for workers of a given educational level (something most studies do not have information on, because business censuses rarely include labor-force characteristics). Even with the effects of plant and worker characteristics removed, blue-collar workers in foreign-owned plants earned about 12 percent more than in domestic plants and white-collar workers about 20 percent more (Lipsey and Sjöholm).

In four East Asian countries for which Ramstetter (1999, table 2) reported wages in foreign and domestic plants or firms, averaged over fourteen- to twenty-three-year periods, wages were higher in the foreign-owned ones, although in Singapore and Taiwan the differences were not significant.

Similar questions can be asked about wages in foreign-owned plants in developed countries. The increasing availability of individual firm and establishment microdata sets has encouraged such studies. In the United States, the linking of Economic Census establishment data with Bureau of 
Economic Analysis (BEA) surveys of inward FDI was a catalyst. Using the BEA-Census data for 1987, the first such match, Lipsey (1994) found that workers in foreign-owned establishments earned 10-12 percent more than those in domestically owned establishments in the same two-digit standard industrial classification (SIC) industries and states. They earned 6-7 percent more in manufacturing and 12-15 percent more in other industries. Howenstine and Zeile (1994), using access to more-detailed information by industry and location not available outside the Department of Commerce, found similar differentials in manufacturing, all of which they could explain by differences in establishment size. Using individual manufacturing-plant data, Doms and Jensen (1998) found that even controlling for four-digit industry, state, plant size, and plant age, foreign-owned plants paid higher wages. They attributed the higher wage in foreign plants to the fact that they were parts of multinational firms, a theory they felt was confirmed by the fact that the highest wages of all were paid by domestic plants that were parts of U.S. multinational firms. One question about this comparison is whether foreign subsidiaries in the United States were comparable to the establishments of U.S. multinationals, since the latter could include firm headquarters operations, a high-paid category probably not part of the U.S. operations of foreign multinationals.

A recent paper used both the 1987 and 1992 BEA-Census matches for establishments, combined into state by detailed industry cells for foreignowned and domestically owned establishments (Feliciano and Lipsey 1999). Foreign-owned establishments in the United States paid higher wages than domestically owned ones in all industries taken together, by 23 percent in 1987 and 15 percent in 1992 (table 2). Once average establishment size, education levels in the state and industry, state unionization levels, and percent female in the state labor force were accounted for, and industry dummies were included, there was no significant difference in manufacturing. However, foreign-owned establishments paid higher wages in nonmanufacturing, by 8.5 to 9.5 percent (tables $3 \mathrm{~A}$ and $3 \mathrm{~B}$ ).

While the United States has been the subject of the largest number of studies, there have been some for other developed countries as well. An early study of American direct investment in Australia (Brash 1966) concluded, from a survey, that "it . . . appears beyond a doubt that even within each industry American-affiliated firms on average pay higher total incomes to their employees than do firms without American connections" (129). Globerman, Ries, and Vertinsky (1994) reported higher wages in foreign-owned plants in Canada.

In recent years, establishment microdata have become available for the United Kingdom, and these have been used for wage and other comparisons. Griffith and Simpson (2001) report that foreign-owned establishments in the United Kingdom paid higher wages than domestically owned establishments for both operatives and administrative and technical em- 
ployees, in both 1980 and 1995. The margin was larger for the lower-skill employees, and widened considerably over the period. An earlier paper (Griffith 1999) compared wages in foreign-owned plants of companies based in France, Germany, Japan, and the United States with those in domestically owned plants. It found no significant differences for 1980, except in U.S.-owned plants, but higher wages in foreign-owned plants in 1992, by margins ranging from 8 to 25 percent (Griffith, 428). In the motor vehicle and engines industry, examined in more detail in the article, there were only small margins for operatives, 2 to 4 percent, but foreign-owned plants paid around 25 percent more to administrative, technical, and clerical workers (431).

A set of "survivors," establishments present in the U.K. Annual Census of Production (or ARD) throughout the period 1973-1993, was assembled by Oulton (2001). He reports that foreign-owned establishments paid average wages for operatives that were above the average for U.K.-owned establishments by 17 percent for non-U.S. establishments and 26 percent for U.S.-owned establishments. The margins for administrative, technical, and clerical (ATC) employees were 12 and 24 percent. The plants differed in other respects as well: foreign-owned plants, and especially U.S.-owned plants, were characterized by higher capital per worker, much higher intermediate input per worker, and higher proportions of ATC employees (129). Although there is no evidence on worker quality, Oulton attributes the wage differential to higher human capital per worker in the foreign plants, because "companies do not pay higher wages out of the goodness of their hearts" (130). A set of regressions including industry dummy variables indicates that industry composition accounts for little of the differential. Within industries, U.S.-owned establishments paid 14 to 15 percent more than domestic establishments, and other foreign establishments paid 10 percent more to operatives and 8 percent more to ATC workers (132).

Using a large sample of U.K. firms from 1991 to 1996, Girma, Greenaway, and Wakelin (2001) reported an overall wage differential of 14 percent in favor of workers in foreign-owned firms, and a differential of almost 10 percent when industry and scale of operations are taken into account. In addition, wage growth was higher by 0.4 percent per year in the foreignowned firms (tables 1 and 2). They summarized their reading of earlier literature as showing "considerable evidence to support a wage differential in favour of foreign owned firms" (121).

Driffield and Girma (2003) reported that foreign-owned establishments in the U.K. electronics industry in 1980 to 1992 paid wages higher by 7.6 and 6.0 percent for skilled and unskilled workers, respectively, and also employed a higher proportion of skilled workers (14).

Since there is always a problem of the effect of unknown firm characteristics on these comparisons, a tempting solution is to observe firms that are acquired by foreign owners. That solution is rare because of the lack of ac- 
cessible data, but Conyon et al. (1999) were able to construct panels of firms in the United Kingdom taken over by domestic and foreign acquirers and matching data for over 600 firms that did not change ownership. At the time of acquisition, the firms acquired by foreigners paid wages about the same as those of firms acquired by domestic owners. However, in the first, second, and third years after acquisition, firms acquired by foreigners raised their wages faster than did firms acquired by domestic owners (table 5). Controlling for fixed firm and industry effects and aggregate time shocks, the authors found that wages rose by 3.4 percent in firms acquired by foreigners and fell by 2.1 percent in firms acquired by domestic owners. Controlling also for firm size and industry wages hardly changed the results. Adding productivity change as a control variable eliminated the differential in favor of foreign firms (p. 9 and table 6), but if one is interested in measuring wage differentials rather than explaining them, productivity change is not an appropriate control.

The evidence seems to me overwhelming that foreign-owned firms in all kinds of economies pay higher wages than domestically owned firms. It is harder to say whether they also pay a higher price for labor-that is, a higher wage for workers of a given quality - although one of the few studies that incorporates quality measures finds that they do. Much of the differential, all of it in some studies, can be associated with the larger size of the foreign-owned operations. However, higher capital intensity and higher inputs of intermediate products, leading to higher productivity, are also important. If regions or countries encouraging inward investment are interested in encouraging high-wage plants, foreign investors seem to meet that desire.

\section{Wage Spillovers}

Whether or not foreign-owned firms in a country pay higher wages than domestic firms, their presence might still affect the level of wages in domestically owned plants. Such effects are referred to as wage spillovers to domestically owned plants. They would not take place in the world envisioned in the Findlay $(1978,8)$ model. There, "[t]he economy is considered able to draw on a reservoir of labor in a 'peasant hinterland' as in the famous model of Arthur Lewis (1954) and also on a substantial 'industrial reserve army' of urban unemployed." However, domestic firm wage effects from inward investment could take place in any world where the supply curve for labor was not horizontal.

Calculations of wage spillovers in two developing countries, Mexico and Venezuela, are included in Aitken, Harrison, and Lipsey (1996). Impacts of shares of employment in foreign-owned plants in an industry and region on wages in domestically owned establishments were measured. In Mexico, wages in domestically owned plants appeared to be lower where foreign ownership was high, but the coefficients were not statistically significant. 
However, in Venezuela, there seemed to be a significant negative influence of foreign presence on wages in domestically owned plants. To some extent, this result could reflect a reallocation of the labor force to foreign plants, through the "poaching" of better workers or the acquisition of higherpaying plants by foreigners. However, if this had been the whole story, there would not have been, as there was, a positive effect of higher foreign ownership on total industry wages.

Lipsey and Sjöholm (2003, 26-27) made a variety of calculations of spillovers from foreign presence to wages in domestically owned establishments in Indonesia, calculating foreign presence at various levels of industry and geographical detail. In every variant, there were significant spillovers to domestically owned establishments. The coefficients on foreign shares in wage equations were larger than the observed wage differentials, suggesting some impact through increases in the demand for labor. The coefficients were generally higher for white-collar than for blue-collar workers.

In their study of South Carolina counties described below, Figlio and Blonigen (2000) did not have the data needed for testing for spillovers from inward investment. However, they concluded that the effect of the investment on aggregate wage levels was so large that it could not have been confined to the foreign plants themselves, and must have involved some spillovers to domestically owned plants $(352, \mathrm{n} 12)$.

In Feliciano and Lipsey (1999), the existence of two years of data permitted the authors to examine the effects of changes in the extent of foreign ownership in the United States in a state by industry cell on wages in domestically owned establishments. In manufacturing, there were no significant effects (table 4a). In nonmanufacturing industries, there were large and statistically significant effects on domestic firm wages, although the significance became marginal when state by industry education levels were added.

Girma, Greenaway, and Wakelin (2001) test for wage spillovers to domestic firms in their U.K. company data set for the 1991-1996 period and find no overall spillover effect on wage levels and a small negative effect on wage growth (128). The only firm characteristic that appears to influence the extent of wage spillovers is the gap in productivity between a firm and the firm in the industry at the 90th percentile in productivity. The larger the productivity gap, the smaller the wage spillover. The only industry characteristic that affects wage spillovers is the degree of import penetration. The higher it is, the larger the wage spillover.

Some of the literature on wage spillovers from foreign-owned to domestically owned firms has recently been reviewed by Görg and Greenaway (2001). They summarize the results of panel data studies as showing mostly negative spillovers and cross-section studies as showing positive spillovers. There is no overlap in the countries studied, but the authors are skeptical 
about all findings from cross-section studies on the ground that they cannot take account of unknown firm characteristics. My own judgment is that there are enough indications of positive wage spillovers, even in panel data studies, to preclude any conclusion that they are typically negative. What is needed most is more consideration of the different circumstances and policies of countries, industries, and firms that promote or obstruct spillovers.

\section{Effects on Average Wages}

Whether or not wages are higher in foreign-owned plants than in domestically owned plants, and whether or not, where there are higher wages, they spill over to domestically owned plants, a higher degree of foreign ownership could affect the average level of wages in a country or industry. It might do so either by raising the demand for labor or through the higher wages paid by the foreign plants themselves.

Aitken, Harrison, and Lipsey $(1996,352)$ reported that, even though there were no spillovers or negative spillovers to domestically owned plants in Mexico and Venezuela, there was a significant effect of foreign ownership shares in raising average industry wages. The effect was larger for skilled workers than for unskilled, and larger in Venezuela than in Mexico.

Feenstra and Hanson (1997), defining skilled workers simply as nonproduction workers, found that a higher level of maquiladora activity in a Mexican industry within a state led to a higher share of total wages' going to skilled workers. They interpreted this increase in the nonproduction wage share as implying a rise in the demand for skilled labor relative to unskilled labor resulting from the growth in maquiladora production by foreign, mainly U.S., firms. The increase in the wage share of nonproduction workers could be a combination of relative wage increases for them or relative increases in their numbers. However, there is some evidence of particularly large relative wage growth for nonproduction workers in the border region, where most of the maquiladoras are located, in the periods after investment rules were liberalized.

The effect of changes in foreign ownership from 1987 to 1992 on average wages in state by industry cells in the United States were found to be insignificant in manufacturing by Feliciano and Lipsey (1999, tables 5a and $5 b)$. However, outside the manufacturing sector, increases in foreign ownership were associated with increases in average wages.

One avenue of relative wage increases that might be associated with increases in foreign ownership is skill upgrading, shifting the demand for labor in an industry toward higher skill. Blonigen and Slaughter (2001), measuring skill upgrading by the share of skilled wages in the total wage bill, find no evidence of such an effect from increases in foreign presence in U.S. manufacturing industries, a result that matches Feliciano and Lipsey (1999). They find some negative effect from Japanese investment in U.S. 
manufacturing, but other studies have shown that Japanese investments are not typical.

In a more local study, Figlio and Blonigen (2000) reported that, in South Carolina, the addition of foreign-owned manufacturing plants was associated with increases in real wages for all workers in the same industry and county. The gain was much larger than that from the addition of new, domestically owned plants.

I would summarize the sparse evidence on overall wage levels as pointing to positive effects of FDI activity. When there are no spillovers, the effect might be wholly from the higher wages offered by the foreign firms, or it might reflect the impact of foreign firms on the aggregate demand for labor. When there are positive spillovers, they add to the impact of the foreign firms. Even when there are negative spillovers, they do not seem to be large enough to offset the positive effect of the foreign firms' high wages or the effects of increased demand for labor.

\subsubsection{Host-Country Productivity}

The issues that arise with respect to measuring effects on wages in host countries are also involved in judging effects on productivity. The impact on the host countries in this respect presumably stems mainly from the superior efficiency of the foreign-owned operations. The first question, then, is whether foreign-owned firms or establishments are more efficient. If they are, the second question is whether their superior productivity spills over to locally owned firms in their industries, or their industries within their regions, or related industries. Locally owned firms might increase their efficiency by copying the operations of the foreign-owned firms, or be forced by competition from foreign-owned firms to raise their efficiency to survive. On the negative side, it is conceivable that foreign-owned operations are more efficient only because foreigners have taken over the moreefficient local firms, leaving the less efficient in local ownership. Or by taking markets from local firms, foreign-owned firms might force the locally owned firms into less-efficient scales of production. The third and broadest question is whether, as a result of the operations of foreign-owned firms, there are improvements in aggregate industry efficiency. Those could arise from spillovers, but they could come simply from the higher efficiency of foreign firms, even if the higher efficiency is confined to the foreign firms. There could also be increases in aggregate productivity without any visible productivity differentials between foreign-owned and domestically owned firms, if the industry were sufficiently competitive that the entry of foreignowned firms forced their domestically owned competitors to match them quickly to survive. These possibilities point to the importance of examining not only firms that remain in an industry over the period of observation, but also firms that enter or exit, because they may account for many of the changes in productivity for an industry or country. 
The choices in defining efficiency range from value added per unit of labor input (the simplest) to value-added per unit of labor and capital input and value of output per unit of labor, capital, and intermediate product input. Some studies fit production functions that also incorporate scale economies. The result is to ignore any host-country benefit from the acquisition of physical capital, or from any advance in technology that consists of the adoption of more capital-intensive methods of production or larger scale production.

Most theoretical discussions of the possible role of inward investment refer to the transmission of superior technology. The examination of productivity is an attempt to measure technology gaps and changes in technology. That is a narrow view of multinationals' technology advantages, which may consist more of their knowledge of world markets or methods of coordinating production over many countries. Almost all the measurement is confined to manufacturing, a large part of multinational activity, but far from the whole of it.

Many of the problems in studying productivity involve the measurement of capital input. Most sources of establishment data either do not report capital stocks, or report nominal values. These are likely to bear a small resemblance to market values, especially in countries that have undergone major inflation. Where even nominal capital values are missing, they are often calculated from past expenditures using the perpetual-inventory method. Such calculations, if done properly, should be based not on general deflators but on capital-goods price indexes - scarce and subject to serious doubts even in the best of statistical systems. The complications suggest caution in drawing conclusions and the advisability of comparing total factor productivity measures with labor productivity and wages to see whether the relations among them are logical.

\section{Productivity Comparisons}

Comparisons of productivity between foreign-owned and domestically owned firms have been far more common than comparisons of wage levels. Much of the productivity literature has been directed at the question of whether there were spillovers to domestic firms, but that question itself implies the expectation that foreign firms are more efficient. The comparisons themselves range from simple overall productivity comparisons to attempts to explain differences between foreign and domestic firms. The explanatory variables, aside from nationality of ownership, include capital intensity, skill intensity, and the scale of operations. These comparisons ask, in effect, whether foreign firms that differ from domestic firms differ because they operate on different production functions or because they operate at different points on the same functions.

Most of the productivity comparisons have been for the manufacturing sectors in developing countries. Blomström and Wolff (1994), examining 
Mexican manufacturing data for 1970 , found both value-added and gross output per employee to have been more than twice as high in multinational corporation- (MNC) owned plants overall as in private domestic plants, and higher in each of 20 individual manufacturing industries (266). Since capital intensities in MNC plants were also much higher, the total factor productivity (TFP) margins were smaller. They were about a third overall, and three industries showed higher TFP in the domestic plants $(267,268)$. Okamoto and Sjöholm (1999), examining Indonesian manufacturing microdata from 1990 to 1995, reported higher foreign shares of gross output than of employment in almost every industry, implying that labor productivity was higher in the foreign-owned plants. Sjöholm (1999) examined Indonesian establishment data for 1980 and 1991, calculating differences in "technology" between foreign-owned and domestically owned establishments. Technology differences were measured as the coefficients on foreign-ownership dummies in equations relating value-added per worker in 1980 and 1991 to scale, 1980 investment expenditure per worker as a proxy for capital intensity, and dummy variables for 1991 observations and foreign ownership. The estimated technology differences were found to be in favor of the foreign-owned establishments in twenty-six out of twentyeight industries. Kokko, Zejan, and Tansini (2001) reported that in Uruguay in 1988, productivity, as measured by value-added per worker, was about twice as high on average in foreign firms as in domestic firms. Haddad and Harrison (1993) found, for Morocco in 1985-1989, that output per worker was higher, and deviations from best-practice frontiers were smaller in foreign-owned firms than in domestically owned firms in twelve out of eighteen industries, and in all eight of the industries in which the differences were statistically significant.

Kathuria (2000) studied Indian firms in twenty-six manufacturing industries over the fourteen years from 1975-1976 to 1988-1989, in a "preliberalization period when Indian industry was highly regulated in terms of industrial and technology policy" (346). The main productivity measurement used was a firm's distance from its industry's technological frontier. In thirteen of the twenty-six industries, a foreign firm was the technological leader, and in fifteen industries, foreign firms were, on average, more efficient. An unusual feature of the data is that because employment was not reported, it was estimated from compensation, assuming that local and foreign firms pay the same wages. That assumption, if we can judge from the wage studies, almost certainly overstates employment in foreign firms and understates their productivity.

Chuang and Lin (1999) report that among a random sample of manufacturing firms in Taiwan in 1991, foreign-owned firms had considerably higher labor productivity than domestically owned firms, but only very slightly higher TFP. The foreign-owned firms were much larger and much more capital intensive. For Malaysia, in 1992-1996, Oguchi et al. (2002) 
found that in manufacturing as a whole, foreign and domestic firms operated with about equal efficiency. However, foreign-owned firms were more efficient in twenty-three out of twenty-nine 3-digit industries, including both nonelectrical and electrical machinery. In the electronic components 5-digit industry, an extremely important one for Malaysia as an exporter, foreign-owned firms were more than 3.5 times as efficient as domestically owned firms.

Comparing foreign-owned with domestically owned firms or plants in five East Asian countries over fifteen- to twenty-year periods, Ramstetter (1999) reported that value-added per employee was higher in the foreignowned plants in all the countries. However, Malaysian data confined to large firms showed higher productivity in the local firms in the later part of the period. Foreign-owned Turkish plants in 1993-1995 had higher productivity than domestically owned plants even when various elements of the production function are taken account of (Erdilek 2002).

There have been fewer examinations of the productivity of foreignowned and domestically owned firms within developed countries. Notable studies of the United States include Howenstine and Zeile (1994), and Doms and Jensen (1998), mentioned earlier. Howenstine and Zeile, using the combined BEA and Census establishment data for manufacturing, found that foreign-owned plants had higher labor productivity than domestically owned ones. They attributed the difference largely to "the tendency for foreign-owned establishments to be concentrated in industries in which productivity is high" and the within-industry differences to "plant size, capital intensity, and employee skill level — rather than foreign ownership per se." Doms and Jensen concluded that foreign-owned plants were superior to U.S.-owned plants of nonmultinational firms, even large firms, in both labor productivity and TFP, but that they were behind plants owned by U.S. multinationals. Thus they find multinationality of the firm to be strongly associated with productivity levels, beyond the association with size and other plant characteristics. A similar hierarchy characterized the ranking with respect to the "number of technologies" used in each type of plant (246-250).

Comparisons within the United Kingdom go back for many years, at least to Dunning (1958) and Dunning and Rowan (1970). Some recent studies, such as Griffith and Simpson (2001), Conyon et al. (1999), and Girma, Greenaway, and Wakelin (2001), are based on individual establishment data from the ARD. Dunning (1958) compared output per man-year in a sample of U.S. affiliates with that in the average U.K. firm (including the affiliates) in ten industrial groups in 1950 and 1954. He found that the U.S. affiliates' productivity was higher in every one (table 16). Dunning and Rowan (1970) applied a number of different tests of efficiency to U.S.- and U.K.-owned firms in the United Kingdom. Although each test seemed subject to one bias or another, the preponderance of evidence pointed to 
greater efficiency in the U.S.-owned firms. Davies and Lyons (1991) reported that gross value-added per worker in foreign-owned manufacturing enterprises in the United Kingdom was, on average, almost 50 percent higher than that of domestically owned enterprises in 1987. No more than half the difference was due to the industrial composition of the foreignowned firms, but some might be due to "differentials in labour skills, capital input, vertical integration, or monopoly power" (593). The differentials within the United Kingdom in 1977 were significantly related to the international productivity differentials, by industry, between the United States and the United Kingdom in 1976. Girma, Greenaway, and Wakelin (2001) found in their data set for 1991-1996 that among firms with no change in ownership, productivity in foreign-owned firms in the United Kingdom was about 10 percent above that for domestically owned firms and TFP about 5 percent higher. Labor and TFP growth rates in foreign-owned plants were higher by about 1.5 percent per year. Conyon et al. (1999) found that acquisitions of U.K. firms by foreigners led to increases in their profitability. A study by Harris and Robinson (2002) of the selection of establishments for foreign acquisition, also based on the ARD, confirmed the suspicion that foreign firms selected relatively high-productivity plants to acquire. Each group of plants was compared to a reference group of plants belonging to U.K. multiplant firms that did not sell any plants to foreign firms during 1982-1992. Plants that were foreign-owned during the whole period were more productive than those in the control group. Plants that were sold by U.K. firms to foreign firms in 1982-1986 or 1987-1992 were still more productive, as were plants sold by one U.K. firm to another. Thus, plant turnover in general seemed to involve relatively productive plants.

The evidence on productivity, whatever the measure, is close to unanimous on the higher productivity of foreign-owned plants in both developed and developing countries. Some of that higher productivity, but not all in most comparisons, can be attributed to higher capital intensity or larger scale of production in the foreign-owned plants.

\section{Productivity and Knowledge Spillovers to Domestic Firms}

Theories of the effect of direct investment on host countries have generally taken it for granted that foreign-owned firms possessed superior technology and that some of that technological knowledge spills over to the host-country economy. Findlay (1978) hypothesized that "the rate of change of technical efficiency in the backward region is an increasing function of the relative extent to which the activities of foreign firms with their superior technology pervade the local economy" (5). He also combined with that assumption the idea that the larger the gap in technology, the faster the transmission, provided that "the disparity must not be too wide for the thesis to hold" (2). Wang and Blomström (1992) added, as expla- 
nations for the speed of transmission, the characteristics of the hostcountry environment and host-country firms. The transmission of technology would be accelerated by a more competitive business environment and greater investment in learning and imitation by competing hostcountry firms (153).

Most studies of productivity spillovers from foreign investment assume that they occur mainly in the industry in which the foreign firm operates. Blomström and Kokko (1998) refer to the literature on backward linkages as examples of spillovers outside those industries, to supplying industries. These arise partly from efforts by multinational firms to improve the quality of the intermediate products they buy locally, sometimes under duress. However, they may arise without explicit help, from the competition among local firms to become the suppliers to the multinationals. The only statistical examination of this issue they report is from an unpublished paper on Venezuela by Aitken and Harrison (1991), which reported negative effects of FDI in an industry on productivity in upstream industries. The reason offered was that foreign firms shift the demand for intermediate inputs from domestic to foreign producers, reducing the scale of output, and therefore productivity, in domestic production. The paper did, however, report positive effects of FDI on downstream industries. These calculations do not appear in the later, published, version of the paper. On the whole, the interindustry effects of foreign participation have received a great deal of speculation, but little statistical testing. However, a recent examination of the existence of spillovers in Lithuanian manufacturing industries from 1996 to 2000 (Smarzynska 2002) concluded that there were positive spillovers through backward linkages. The evidence for productivity gains by supplying firms was stronger for foreign affiliates in the same region as the supplier, and was larger for foreign affiliates serving the host-country market than for those serving export markets.

Among studies of spillovers within industries, one for Venezuela by Aitken and Harrison $(1999,616)$ found that "increases in foreign equity participation are correlated with increases in productivity" for small plants, but that increases in foreign ownership in an industry negatively affected productivity in domestically owned plants in the same industry. The positive effects within the foreign plants exceeded the negative effects, but only slightly. The positive relationships found by others, they argued, were due to the tendency of foreign firms to invest in high-productivity sectors and firms $(616,617)$. The authors report similar findings for Indonesia, except that there the positive effects are larger than in Venezuela and the negative effects smaller (617).

Using data from the Mexican Industrial Census for 1970, Blomström (1983) and Blomström and Persson (1983) found that the labor productivity in domestically owned plants was positively related to the extent of foreign presence in the industry. That was true even when differences in capi- 
tal intensity and in the quality of labor employed were accounted for. In a study based on the same Mexican census, Kokko (1994) confirmed the existence of productivity spillovers to locally owned firms and found some evidence that high capital intensity in an industry and a high level of technology might inhibit spillovers. A stronger conclusion was that the combination of large technology gaps between foreign and domestic firms and large foreign market shares, which the author describes as "enclave" situations, discourages spillovers. Blomström and Wolff (1994), on the basis of Mexican census data, concluded that higher foreign shares in an industry in 1970 led to higher rates of productivity growth in locally owned firms over the next five years. Local firm productivity growth was higher in industries in which the local firms' productivity levels were initially closer to those of the foreign-owned firms (270). Higher foreign shares in an industry were also associated with faster convergence of Mexican-industry productivity toward U.S.-industry productivity levels, again more strongly in industries in which the initial gap was smaller (275).

Kathuria (2000), in a study of spillovers to Indian manufacturing firms, found that a division of the manufacturing sectors into "scientific" and "nonscientific" subgroups showed positive spillovers in the scientific sectors, but none in the nonscientific ones. One conclusion was that "spillovers are not found to be automatic consequences of foreign firms' presence, but they depend to a large extent on the efforts of local firms to invest in learning or R\&D activities so as to decodify the spilled knowledge" (364). He thus supports the theoretical model proposed by Wang and Blomström (1992). Buckley, Clegg, and Wang (2002) studied several types of spillovers in China in a study based on the Third Industrial Census of China, for 1995, early in the Chinese FDI boom. Higher foreign presence in an industry resulted in higher labor productivity in domestically owned firms, holding constant capital intensity, R\&D intensity, and labor quality.

A pioneering attempt to measure impacts on domestic firms in developed countries was Caves (1974), on Canada and Australia. He found some evidence that higher shares in an industry for foreign subsidiaries were weakly, and negatively, related to the profitability of Canadian firms, a possible indication that foreign firms raised the level of competition and reduced the excess profits that had been earned by their local rivals. However, he was not certain that the relation was not due entirely to differences in the attainment of economies of scale. In Australian manufacturing, he found that "higher subsidiary shares do apparently coincide with higher productivity levels in competing domestic firms" (190). However no such relationship could be found between changes in foreign shares and changes in the productivity of domestic firms, a fact that reduced his confidence in the significance of the finding for levels (190-191). A later study by Globerman (1979), for a sample of manufacturing industries in 1972, concluded 
that differences across Canadian industries in labor productivity "derive, in part, from spillover efficiency benefits associated with foreign direct investment" (53).

Haskel, Pereira, and Slaughter (2002) use British panel data to relate changes in TFP of domestically owned British establishments to changes in foreign presence, measured by shares in employment, in the establishment's industry, region, or industry in the region. Significant evidence is found for positive spillovers within industries. Positive spillovers are found to come from U.S. and French presence, but Japanese presence produces negative spillovers. The authors conclude that, of the aggregate increase of 11 percent in British TFP from 1972 to 1992, 5 percent could be ascribed to spillovers from foreign-owned plants (17). Girma, Greenaway, and Wakelin (2001) find no significant effect of foreign presence, measured by shares of employment or output, on the labor productivity or TFP of U.K. firms in general during 1991-1996. However, the higher the skill level of the industry, and the greater the degree of foreign competition in the industry, the larger the productivity spillover. And the larger the individual firm's distance from the productivity leader in its industry (the firm at the 90th percentile in TFP), the smaller the spillover (129). Thus they point to the importance of firm and industry characteristics in determining the extent of spillovers, as well as, possibly, trade policy, as represented by import penetration levels. Examining changes in productivity in domestically owned U.K. firms between 1989 and 1992, Driffield (2001) finds no spillovers related to the amount of sales by foreign-owned firms or their $\mathrm{R} \& \mathrm{D}$ stock. However, the growth of labor productivity among foreignowned firms in the previous period, from 1986 to 1989, did lead to productivity growth among domestically owned firms in the same industry. $\mathrm{He}$ concluded that "the foreign productivity advantage was responsible for an average increase in domestic productivity of 0.75 per cent a year" (113). Girma and Wakelin (2000), also using U.K. microdata for manufacturing establishments, found evidence of positive spillovers to domestic firms in the same region as the foreign firms, but some evidence of negative spillovers outside the regions. They also concluded that low technology gaps between domestic and foreign firms and location in more technologically advanced regions promoted spillovers.

In a study of labor-productivity spillovers in Italian manufacturing in 1988, Imbriani and Reganati (1997) found that, across all industries, foreign shares in employment were positively associated with revenue per worker in domestically owned firms. When industries were divided according to the size of the technology gap between foreign-owned and domestically owned firms, there was a positive effect of foreign presence in the sectors with small gaps, much larger than that for all industries together. However, there was a negative effect on domestic firms, smaller, but statistically significant, in industries where the technology gap was large. 
Blomström and Kokko $(1998,24)$ end a review of productivity spillovers to host countries by concluding that "such effects exist and . . . they may be substantial both within and between industries, but there is no strong evidence on their exact nature and magnitude." Furthermore, "the positive effects of FDI are likely to increase with the level of local capability and competition.” Blomström, Kokko, and Globerman (2001), in a later review of this literature, summarize the "limited evidence" for developed countries as pointing to a dependence of productivity spillovers on the absorptive capacity of domestically owned firms. They conclude that small productivity gaps encourage spillovers, while large gaps inhibit them. They report similar findings among developing countries, and they attribute the more mixed results on spillovers in studies of such countries to the greater frequency of wide technology gaps between foreign and local firms (4243). They also report that spillovers are encouraged by vertical linkages between MNCs and local firms, a characteristic that would also depend partly on local firm capabilities.

Görg and Greenaway (2001) summarize the results of the productivity studies with respect to spillovers from foreign-owned to domestically owned firms by saying that "only limited evidence in support of positive spillovers has been reported. Most work fails to find positive spillovers, with some even reporting negative spillovers, at the aggregate level" (23). In contrast, Görg and Strobl (2000) take spillovers for granted in their study of firm survival in Ireland, and find that foreign presence reduces exit by domestically owned firms, at least in high-tech industries, an effect they attribute to spillovers. Görg and Strobl (2002) find also that foreign presence encourages entry by domestically owned firms. Görg and Greenaway (2001) are inclined to attribute the variety of findings on spillovers mainly to the difference between cross-section and panel data studies. However, there is evidence that differences among firms in their capabilities, differences among industries in their characteristics, and differences among countries in both capabilities and policies may be important explanations for this diversity of results. A more formal "meta-analysis" of spillover findings from twenty-one studies by Görg and Strobl (2001), using the $t$ statistic in spillover equations as the dependent variable, concluded that the use of cross-section data was a strong positive influence. Of the eight studies that used panel data, four found significant negative spillovers, confirming the importance of the distinction between panel data and crosssection results.

Since quite a few studies report that spillovers are discouraged by very large gaps between foreign and domestic firms, by restrictive trade regimes, or by other institutional factors, the composition of the sample of countries covered by the small collection of panel data may be important. Of the four developing countries with panel data included by Görg and Strobl (2001) - Colombia, India, Morocco, and Venezuela—none are listed as 
"outward-oriented" during the period covered by the panel data in World Bank (1987). India is called "strongly inward-oriented" and Colombia "moderately inward-oriented," and Morocco and Venezuela are not rated. Of forty-two countries ranked by Wheeler and Mody (1992), Venezuela is ranked in the next-to-lowest category with respect to openness. In World Economic Forum (2002), Colombia, India, and Venezuela are in the lower half of developing countries with respect to "Technology" and "Growth Competitiveness." Perhaps these are not of a random sample of developing countries and are not the most likely ones in which to find spillovers.

The studies of productivity comparisons between foreign-owned and domestically owned firms and establishments have generally found that foreign-owned entities had higher productivity. Almost all the studies showed that some of the higher labor productivity in the foreign-owned entities could be explained by their greater capital intensity, their larger size, and their greater use of purchased inputs. The same variables, except for the capital intensity (and sometimes the purchased inputs), accounted for the differences in TFP. Even after these factors are removed from the comparison, it is frequently, but not always, found that there is a residual productivity advantage for the foreign-owned firms. There is more logic to removing the influence of these other factors in comparisons within developed countries than in comparisons within developing countries. In developed countries it can more easily be assumed that there are domestic firms capable of producing with the same capital intensity and managing plants of the same size. In developing countries, there may be a better case for suggesting that the technological impact of the foreign firms is broader than what is measured by their TFP. It also involves their knowledge of how to produce on a large scale and market the output, how to use capitalintensive techniques, and how to combine local inputs with purchased inputs from the multinational itself or other suppliers. If that is the case, one should study differences and look for spillovers not only in TFP but also in plant size, capital intensity, and use of other inputs.

An unusual study of spillovers to the host country that was focused directly on spillovers of knowledge, and did not depend on TFP measures at all, was Branstetter's (2000) examination of patent citations. The higher the level of Japanese affiliates sales in the United States, lagged two years, the larger the number of U.S. citations to Japanese patents in U.S.-firm patent applications. A recent paper by Singh (2002), analyzing citations in U.S. patent filings, finds evidence of knowledge flows from local firms to multinationals' foreign affiliates and from the affiliates to local firms, and summarizes other studies based on patent citations. This line of research is a promising addition to studies of knowledge diffusion, bypassing the problems of productivity measurement.

Another suggestion that common measures of technology-transfer miss the point was made in an analysis of the impact of inward FDI on China 
(Chen, Chang, and Zhang 1995). It refers to "FDI's less than satisfactory contribution in high technology transfer to China" (700), which it explains by the high proportion of FDI coming from Hong Kong and Taiwan. The impact of such investment was that it brought "the modern concept of management and marketing" (700). That is a contribution that would be missed by standard measures of TFP.

Productivity-spillover studies typically assume that the effect on domestic firms should be linearly or log-linearly dependent on the foreign share of an industry. It is not obvious that this should be the case, particularly as the foreign share goes to high levels. Spillover is not obviously maximized at a foreign share of 100 percent. One way this problem is recognized is in Kokko (1996), where industries with foreign shares above 50 percent are dropped, being categorized as "enclave industries."

A broader problem is that there is little basis for assuming any particular form of the relationship. Some mechanisms might suggest a linear relation to the foreign participation share, but others might suggest a strong effect from foreign entry, but little effect from changes in share.

One of the few studies to examine productivity growth in general, rather than only spillovers to domestic firms was a cross-country, cross-industry study covering nine Organization for Economic Cooperation and Development (OECD) countries from 1979 to 1991, by Baldwin, Braconier, and Forslid (1999). They examined labor productivity growth in seven broad industry aggregates. Although the title of the paper refers to spillovers, no distinction was made between productivity in foreign-owned firms and that in domestically owned ones. This does not match the usual definition of spillovers, in which that distinction is important, but the results are of interest because they measure the total impact on an industry, a topic rarely studied. The authors reported that higher FDI penetration levels led to more rapid growth in industry labor productivity.

Another of these rare attempts to measure effects on industries as a whole, rather than only on domestically owned firms, was an unpublished paper by Nadiri (1992). He used U.S.-owned affiliates' stocks of plant and equipment, rather than financial flows, as the measure of foreign investment in the manufacturing sectors of four developed host countries: France, Germany, Japan, and the United Kingdom. United States-owned affiliates' capital reduced the cost and price of output, and increased output and TFP. The increase in output raised the demand for labor and materials, but the higher U.S. FDI capital reduced the demand for labor and materials per unit of output.

As mentioned earlier, a serious problem with TFP measures, especially in developing countries, is the weakness of the data on capital stocks. Another problem with productivity comparisons and productivity-spillover measures is that it is extremely rare to find any measure of output other than value-added, or even any comparison with alternative measures. The 
assumption underlying the measurement of output by value-added, which is an input measure, is that the firm or establishment is operating in a competitive environment. If a firm paid wages that exceeded worker productivity, for example, output would not be exaggerated because profits would be correspondingly reduced, and value-added would still represent output. However, if a firm operated in a protected market because it was government owned or because it sold to the government, or because it sold to its parent, or because competition was limited in other ways, its value-added output measure would be inflated. Similarly, a firm earning monopoly profits would appear to be highly productive even if wages were not inflated, because value-added would be inflated. Thus, for example, if the entry or growth of foreign-owned firms broke up a local-firm monopoly, the decline in local-firm monopoly profits would appear in the data disguised as a decline in their productivity resulting from foreign entry.

While the technological superiority of foreign firms seems clear, as is expected on theoretical grounds, the evidence on spillovers is mixed. No universal relationships are evident. However, there is substantial evidence from several countries that inward FDI has been most beneficial to the productivity of local firms where the local firms are not extremely far behind the multinationals' affiliates.

\subsubsection{Exports and the Introduction of New Industries}

One of the main contributions of inward direct investment in some cases has been to introduce new industries to a country or drastically change the composition of production. Lipsey (2000) describes the large role of U.S. affiliates in the electronics industry in East Asia, especially in the early development of the industry. The earliest data available show U.S. affiliates accounting for three-quarters of exports in some cases, with the share declining over time. Labor-intensive industries, such as food, textiles, and apparel, declined, while the share of chemical and machinery industries in exports rose to more than half (163). Some of the country studies in Dobson and Chia (1997) are summarized as showing that "[f]oreign firms ... saw a way to integrate these countries into worldwide networks of production. . . . Foreign firms supplied the technology and the links to other parts of the production networks that completed the set of resources necessary for the growth of these industries" (163).

In a set of country- and industry-specific case studies collected in Rhee and Belot (1990), the authors refer in their summary to "the critical role of transnational corporations (TNCs) in the transfer of technical, marketing, managerial know-how to developing countries-a role more important than the transfer of financial resources associated with DFI [direct foreign investment] by TNCs" (viii). The development of plywood manufacturing and export in Indonesia in the 1980s was started by firms from Korea and Taiwan. They had developed their skills when these countries replaced 
Japan in plywood manufacturing and transferred "technical, marketing, and managerial know-how through joint ventures" after the home countries lost their comparative advantage as their wages rose (Rhee and Belot 1990, 22-29). A military-uniform exporter from Zambia grew from a joint venture with a German firm that originally was aimed at the domestic market but could draw on export experience from the German parent when selling locally became impractical (33-34). In Côte d'Ivoire, a joint venture with a French company, experienced in marketing and technically skilled, brought the country into the semiprocessed-cocoa market (39-40). The ingredients for expansion of Jamaican exports of garments to the United States were provided by a joint venture with a Korean company that supplied "effective management, effective training in advanced technology, efficiency of operations, and marketing skills and channels" (42). Not all the catalysts described in the report involved FDI, but quite a few of them did, and the contribution they made seemed to have little to do with supplying capital and much to do with technology and marketing knowledge. Buckley, Clegg, and Wang (2002) found, for Chinese manufacturing industries in 1995, that a higher foreign share of capital in an industry increased the development of new and high-tech products by domestically owned firms, as well as their export intensities.

Since export data are available in much more detail than production data in many countries, the development of new industries or subindustries or of new varieties of products may be evident most clearly in the growth of exports. Blomström (1990) describes the role of multinationals in shifting production in developing countries toward tradable goods and, among tradables, away from import substitution and toward export markets. The role of access to parent networks in promoting exports by U.S. affiliates in Asia is assessed in Lipsey (1998).

Ireland was an unusual example for Western Europe, in that it went from being extremely hostile to inward investment until the late 1950s, to welcoming and even favoring it by tax and other policies. One could not have predicted the current comparative advantage of Ireland from its comparative advantage before inward investment was liberalized, which was that of an agricultural country. The entrance of foreign firms, together with Ireland's joining the European Union, transformed the economy into one where foreign firms, exporting over 70 percent of their output, accounted for two-thirds of manufacturing net output and almost half of manufacturing employment. In relatively high-tech industries, the foreign firms were geared almost entirely to export markets (Ruane and Görg 1999, $51-53)$.

Most of the studies of the effects of FDI on host-country exports examine the behavior of the affiliates themselves, generally finding that they are more export oriented than domestically owned firms. Sousa, Greenaway, and Wakelin (2000) investigated whether the presence and activities of for- 
eign-owned firms affected the exporting of domestically owned firms in the United Kingdom. Using a database of U.K.-owned manufacturing firms from 1992 to 1996, they found that foreign firms' R\&D in the United Kingdom, their exporting, and their importance in U.K. production in an industry were all significantly related to the probability that a domestic firm in that industry would be an exporter. There were also some indications that foreign firms' activities raised the export propensities of domestically owned firms. The only comparable study the authors cite is Aitken, Hanson, and Harrison (1997), for manufacturing establishments in Mexico in 1986-1990. That study found that higher production by foreign-owned firms in a sector, as well as greater export activity by those firms, increased the likelihood that domestic firms would export.

A study of China's aggregate trade and FDI relationships with individual partner countries (Liu, Wang, and Wei 2001) found, in causality tests, that China's imports from a country tended to precede inward FDI from that country, and that inward FDI then preceded exports to the investing country. The initial effect of inward FDI from a country on China's exports to the source country was negative, but all the subsequent lagged terms were positive and much larger, so that the net effect of inward FDI was an increase in Chinese exports to the investing country.

The positive influence of inward FDI on host-country exports seems well established, whatever the mechanism. And the few studies of spillovers of exporting from affiliates to domestic firms point in the same direction.

\subsubsection{Host-Country Growth}

One of the main reasons for examining productivity spillovers from foreign-owned to domestically owned firms is to understand the contribution of inward FDI to host-country economic growth. If the higher productivity of the foreign firms was at the expense of lower productivity in domestic firms, there might be no implications for aggregate output or growth. There could be growth effects without spillovers, just from the operations of the foreign firms themselves, but that possibility is rarely explored, except by implication in studies of the impact of the entrance or growth of foreign firms on the output or growth of a country.

An optimistic appraisal of the impact of inward FDI was that of Romer (1993a), who suggested that, for a developing country trying to keep up with or gain on more advanced countries, the main obstacle was the gap in knowledge or ideas rather than in physical capital. Much of that capital was the human or organizational capital of multinational firms. For more rapid growth, "one of the most important and easily implemented policies is to give foreign firms an incentive to close the idea gap, to let them make a profit by doing so . . by creating an economic environment that offers an adequate reward to multinational corporations when they bring ideas from the rest of the world and put them to use with domestic resources" (548). 
One way in which the influence of FDI on host-country growth has been studied is through comprehensive cross-country studies in which the rate of growth of real gross domestic product (GDP) or GDP per capita is related to the stock or inflow of FDI. In general, the results of these studies indicate that the size of inward FDI stocks or flows, relative to GDP, is not related in any consistent way to rates of growth. However, most studies find that among some subsets of the world's countries, FDI, or FDI in combination with some other factors, is positively related to growth. Blomström, Lipsey, and Zejan (1994) did find that, among developing countries, from 1960 to 1985, ratios of FDI inflow to GDP in a five-year period were positively related to growth in the subsequent five-year period. However, when the developing countries were divided between higher- and lower-income countries, FDI promoted growth only in the higher-income countries. Borensztein, De Gregorio, and Lee (1998) found, among sixty-nine developing countries from 1970 to 1989, that FDI inflows, by themselves, only marginally affected growth; but that FDI interacted with the level of education of a country's labor force was a significant positive influence. That relationship was confirmed for FDI inflows in five-year periods and growth in subsequent periods in Lipsey (2000).

An explanation for the variety of results was offered by Bhagwati (1978), who suggested that the growth effects of inward FDI could be favorable or unfavorable, depending on the incentives offered by host-country trade policies. The efficiency of FDI in promoting growth would be increased by an export-promotion policy and decreased by an import-substitution policy. A test of this hypothesis by Balasubramanayam, Salisu, and Sapsford (1996) persuaded the authors that in ten to eighteen export-promotionpolicy developing countries, higher inward FDI flows were associated with faster growth. No effect was found in the remaining developing countries, presumably following import-substitution trade policies. This idea that the effect of inward FDI on growth is enhanced by liberal trade and investment policies in host countries is emphasized in Moran (2002, chap. 9).

A panel data study of aggregate country effects, without industry distinctions (de Mello 1999), found that FDI inflows raised growth in both developed and developing countries. In developed countries, FDI inflows raised TFP growth, but not fixed investment, while in developing countries it raised fixed investment, but not TFP growth. An earlier survey of eleven studies by de Mello (1997) found a majority reporting positive effects of FDI inflows on growth, and stronger effects associated with greater openness or export-promotion policies and with a higher level of development. The influence on technological change, and particularly domestic factor productivity, was in the same direction, but observed in fewer studies, again varying with the same set of country characteristics.

An alternative explanation for the variety of experience with FDI is offered by Alfaro et al. (2002). They find, in a regression analysis for the pe- 
riod 1975-1995 as a whole, and using various measures of financial development, that the existence and extent of local financial markets is an important determinant of the extent to which FDI affects growth. That idea, which they trace back to Goldsmith (1969), among others, is here based on the proposition that in the absence or weakness of local financial markets, local firms are unable to take advantage of the various kinds of knowledge that they gain from the presence of foreign firms.

A recent study including developed and developing countries by Carkovic and Levine (2000) finds no significant effect of FDI inflows over the whole period 1960-1995, and only irregularly significant effects in fiveyear periods. They find that none of the variables found in other studies consistently determine the effect of FDI on growth, although some are significant in some combinations of conditioning variables.

In a narrower group of countries (twenty-five Central and Eastern European and former Soviet transition countries), Campos and Kinoshita $(2002,22)$ find that FDI "is a crucially important explanatory variable for growth," and that the finding survives "correcting for reverse causality, endogeneity, and omitted variable bias." They allege that FDI represents more of a pure transfer of technology in these transition countries than in most developing countries, because these countries were industrialized and had relatively well-educated labor forces.

As with the studies of wage and productivity spillovers, but more so because most of those studies narrowly focus on manufacturing, the studies of the effects of FDI inflow on national economic growth are inconclusive. Almost all find positive effects in some periods, or among some groups of countries, in some specifications, but one cannot say from these studies that there are universal effects. There are circumstances, periods, and countries where FDI seems to have little relation to growth, and others where there seems to be a positive relation.

\subsection{Conclusions}

Among the early fears about the effects of the growth of multinationals on their home countries, the worry that they would cause exports from the home country and aggregate employment to fall has mostly dissipated. There is probably no universal relationship between outward investment and home-country exports, and to the extent that any relationship is present, outward FDI is more often found to promote exports than to compete with them.

There are some indications that multinational operations have led to a shift toward more capital-intensive and skill-intensive production in the United States, as labor-intensive-and particularly unskilled-laborintensive - production has been allocated to affiliates in developing countries. The alternative to this shift may have been a shift to nonaffiliated 
firms in those countries. However, even that reallocation does not appear to have occurred in Sweden or Japan, so it cannot be considered a universal consequence of multinational operations.

One function that outward FDI seems to have played for home countries' firms is that of preserving export markets for the firms even when home-country economic changes such as exchange rate movements, increases in costs, or other events threaten home-country firms' competitiveness. Examples of this defensive role of foreign affiliates can be found for the United States, Japan, and Sweden.

Within host countries, it has been abundantly shown that foreign-owned firms pay higher wages than domestically owned firms. Some, but not all, of the higher wage levels can be associated with characteristics of the affiliates, such as their size and capital intensity. Where it can be measured, higher quality of labor also accounts for some, but again not all, of the difference. Beyond that, there is some evidence that foreign-owned firms pay a higher price for labor, in the sense of paying more for a worker of given quality, but there are not many studies that include data on worker characteristics.

Evidence on wage spillovers (i.e., effects of foreign entry or participation in an industry or region, or industry within a region) on the wages paid by domestically owned firms, is sparse, and not conclusive as to direction. However, there is more evidence that, whatever the extent and direction of spillovers to domestically owned plants, the effect of foreign firms' presence is to raise the average level of wages. The effect may come simply from higher wages in the foreign-owned operations, even without any effect on locally owned ones. It might come from positive spillovers to locally owned plants or from the effects of the increased demand for labor, even if there is no difference in wage levels between foreign-owned and domestically owned plants.

Many wage studies, if they are based on individual firm or establishment data, include controls for plant size and, where possible, for capital intensity and other plant characteristics. They attempt in this way to learn whether wage levels reflect these characteristics other than foreignness itself, since wage levels are, for example, almost always positively associated with establishment or firm size. From a policymaker's point of view, this distillation of the effects of pure foreignness may not be relevant. An expansion of foreign presence may be desirable because foreign firms bring larger-scale, more capital-intensive, or more technically advanced methods of production. It does not matter that an identical domestic firm would produce the same results, because there may not be any such firms, or they may not find it profitable to make these same investments.

Even if foreign entry and larger foreign shares of production almost always raise wage levels, there are some host-country losers from their participation. Small or inefficient local firms may be forced to contract or 
leave the industry altogether. That may be viewed as a healthy redeployment of capital, but it is an explanation for some host-country opposition to foreign multinationals.

Productivity comparisons between foreign-owned and domestically owned firms or establishments almost always find that the foreign-owned firms have higher productivity levels. As with the wage comparisons, some of the differences can be associated with the larger size of foreign-owned plants or other plant characteristics.

Evidence on spillovers of superior foreign productivity to domestically owned firms is mixed. Some observers conclude that there is substantial evidence for positive spillovers and others see the evidence as inconclusive. Even where no spillovers are found to all domestic firms as a group, they are often found for subsets of domestic firms, particularly those not too far behind the foreign firms technologically, or those in higher-technology industries. The mixed story for spillovers, combined with the strong evidence for superior productivity in foreign-owned firms, suggests that overall productivity is improved by the presence of foreign-owned operations.

In many of these productivity studies there has been a substantial effort to calculate TFP comparisons, rather than labor productivity comparisons, and to remove the influence of firm or establishment size. An effort is made, in effect, to learn whether foreign and domestic firms are on different production functions. It is not always clear why it is so important to measure the effect of foreignness alone, untainted by differences in capital intensity and size. Much of the growth of presently developed countries came from increases in the scale of production and in its capital intensity. The contribution of foreign firms may come partly by introducing largerscale or more capital-intensive methods of production, or differences in technology may be inextricably tied to differences in scale and capital intensity.

One frequent effect of foreign entry is the introduction of new industries or products to the host-country economy and the tighter linking of the host country to the world trading system. The contribution of the foreignowned firms is mainly of knowledge, particularly knowledge of demand in the world market, and knowledge about how the host country can find a place in the worldwide allocation of intermediate steps in the path of production that can be geographically separated. By the development of new (to the host country) products, inward direct investment is associated with faster economic growth, although attempts to find a consistent relation between the extent of FDI inflows and national economic growth do not produce strong and consistent relationships.

One issue that is missing from the discussion of effects of FDI-a strange omission from a literature dominated by economists - is the impact on consumers. There could be effects on home-country consumers from imports of cheaper goods produced by foreign affiliates. There could 
be effects on host-country consumers from more efficient production of goods and services sold locally and from the weakening of local-producer monopoly positions. There have been analyses in the trade literature of consumer gains from imports, but studies of host countries ignore the relation of consumer prices to the presence or activities of foreign affiliates.

A proven association of FDI with more trade and faster economic growth would not necessarily please critics of multinationals. Trade links reduce the freedom of action of a country's government domestically, if not that of its people. Fast growth involves disruptions and the destruction of the value of old techniques of production and old skills. Those who value stability over economic progress will not be convinced of the worth of the gifts brought by foreign involvement. That is especially true if the gains are captured by small elements of the population or if no effort is made to soften the impact of the inevitable losses.

\section{References}

Aitken, Brian J., Gordon H. Hanson, and Ann E. Harrison. 1997. Spillovers, foreign investment, and export behavior. Journal of International Economics 43 (12): 103-32.

Aitken, Brian J., and Ann Harrison. 1991. Are there spillovers from foreign direct investment? Evidence from panel data for Venezuela. MIT, Economics Department, and World Bank. November (processed).

1999. Do domestic firms benefit from direct foreign investment? Evidence from Venezuela. American Economic Review 89 (3): 605-18.

Aitken, Brian J., Ann E. Harrison, and Robert E. Lipsey. 1996. Wages and foreign ownership: A comparative study of Mexico, Venezuela, and the United States. Journal of International Economics 40 (3-4): 345-71.

Alfaro, Laura, Areendam Chanda, Sebnem Kalemli-Ozcan, and Selin Sayek. 2002. FDI and economic growth: The role of local financial markets. Harvard Business School, North Carolina State University, University of Houston, and International Monetary Fund. April (Processed).

Australia Productivity Commission. 2002. Offshore investment by Australian firms: Survey evidence. Commission research paper. Canberra: AusInfo.

Balasubramanyam, V. N., M. Salisu, and David Sapsford. 1996. Foreign direct investment and growth in EP and IS countries. Economic Journal 106 (434): $92-$ 105.

Baldwin, Richard E., Henrik Braconier, and Rikard Forslid. 1999. Multinationals, endogenous growth and technological spillovers: Theory and evidence. Center for Economic Policy Research (CEPR) Discussion Paper no. 2155. London: CEPR.

Bergsten, C. Fred, Thomas Horst, and Theodore H. Moran. 1978. American multinationals and American interests. Washington, D.C.: Brookings Institution.

Bhagwati, Jagdish N. 1978. Anatomy and consequences of exchange control regimes. Special conference series on foreign trade regimes and economic development, vol. 11. Cambridge, Mass.: Ballinger. 
Blomström, Magnus. 1983. Foreign investment and spillovers. London: Routledge. 1990. Transnational corporations and manufacturing exports from developing countries. New York: United Nations.

Blomström, Magnus, Gunnar Fors, and Robert E. Lipsey. 1997. Foreign direct investment and employment: Home country experience in the United States and Sweden. Economic Journal 107 (445): 1787-97.

Blomström, Magnus, and Ari Kokko. 1998. Multinational corporations and spillovers. Journal of Economic Surveys 12 (2): 247-77.

Blomström, Magnus, Ari Kokko, and Steven Globerman. 2001. The determinants of host country spillovers from foreign direct investment: A review and synthesis of the literature. In Inward investment, technological change, and growth, ed. Nigel Pain, 34-65. Basingstoke, U.K.: Palgrave.

Blomström, Magnus, Robert E. Lipsey, and Ksenia Kulchycky. 1988. U.S. and Swedish direct investment and exports. In Trade policy issues and empirical analysis, ed. Robert E. Baldwin, 259-97. Chicago: University of Chicago Press.

Blomström, Magnus, Robert E. Lipsey, and Mario Zejan. 1994. What explains the growth of developing countries? In Convergence of productivity: Cross-national studies and historical evidence, ed. William J. Baumol, Richard R. Nelson, and Edward N. Wolff, 243-59. New York: Oxford University Press.

Blomström, Magnus, and Håkan Persson. 1983. Foreign investment and spillover efficiency in an underdeveloped economy: Evidence from the Mexican manufacturing industry. World Development 11 (6): 493-501.

Blomström, Magnus, and Edward N. Wolff. 1994. Multinational corporations and productivity convergence in Mexico. In Convergence of productivity: Crossnational studies and historical evidence, ed. William Baumol, Richard R. Nelson, and Edward N. Wolff, 263-84. Oxford: Oxford University Press.

Blonigen, Bruce A., and Matthew J. Slaughter. 2001. Foreign-affiliate activity and U.S. skill upgrading. Review of Economics and Statistics 83 (2): 362-76.

Borensztein, Eduardo, Jose De Gregorio, and Jong-Wha Lee. 1998. How does foreign direct investment affect economic growth? Journal of International Economics 45 (1): 115-35.

Braconier, Henrik, and Karolina Ekholm. 2000. Swedish multinationals and competition from high- and low-wage locations. Review of International Economics 8 (3) 448-61.

Brainard, S. Lael. 1997. An empirical assessment of the proximity-concentration trade-off between multinational sales and trade. American Economic Review 87 (4): 520-44.

Brainard, S. Lael, and David A. Riker. 1997. Are U.S. multinationals exporting U.S. jobs? NBER Working Paper no. 5958. Cambridge, Mass.: National Bureau of Economic Research, March.

Branstetter, Lee. 2000. Is foreign direct investment a channel of knowledge spillovers? Evidence from Japan's FDI in the United States. NBER Working Paper no. 8015. Cambridge, Mass.: National Bureau of Economic Research, November.

Brash, Donald T. 1966. American investment in Australian industry. Cambridge: Harvard University Press.

Buckley, Peter J., Jeremy Clegg, and Chengqi Wang. 2002. The impact of inward FDI on the performance of Chinese manufacturing firms. Journal of International Business Studies 33 (4): 637-55.

Campos, Nauro F., and Yuko Kinoshita. 2002. Foreign direct investment as technology transferred: Some panel evidence from the transition economies. The Manchester School 70 (3): 398-419. 
Carkovic, Maria, and Ross Levine. 2002. Does foreign direct investment accelerate economic growth? University of Minnesota, Department of Finance. Working Paper, June.

Caves, Richard E. 1974. Multinational firms, competition, and productivity in host-country markets. Economica 41 (162): 176-93.

1996. Multinational enterprise and economic analysis, 2nd ed. Cambridge: Cambridge University Press.

Chédor, Séverine, and Jean-Louis Mucchielli. 1998. Implantation à l'étranger et performance à l'exportation: Une analyse empirique sur les implantations des firmes francaises dans les pays emergents (Implantation abroad and export performance: An empirical analysis of the implantation of French firms in emerging countries). Revue Économique 49 (3): 617-28.

Chédor, Séverine, Jean-Louis Mucchielli, and Isabel Soubaya. 2002. Intra-firm trade and foreign direct investment: An empirical analysis of French firms. In Multinational firms and impacts on employment, trade, and technology, ed. Robert E. Lipsey and Jean-Louis Mucchielli, 84-100. London: Routledge.

Chen, Chung, Lawrence Chang, and Yimin Zhang. 1995. The role of foreign direct investment in China's post-1978 economic development. World Development 23 (4): 691-703.

Chuang, Yih-Chyi, and Chi-Mei Lin. 1999. Foreign direct investment, R\&D, and spillover efficiency: Evidence from Taiwan's manufacturing firms. Journal of Development Studies 35 (4): 117-34.

Conyon, Martin, Sourafel Girma, Steve Thompson, and Peter Wright. 1999. The impact of foreign acquisition on wages and productivity in the U.K. Centre for Research on Globalisation and Labour Markets Research Paper no. 99/8. Nottingham, U.K.: University of Nottingham.

Davies, Stephen W., and Bruce R. Lyons. 1991. Characterising relative performance: The productivity advantage of foreign-owned firms in the U.K. Oxford Economic Papers 43 (4): 584-95.

De Mello, Luiz R., Jr. 1997. Foreign direct investment in developing countries and growth: A selective survey. Journal of Development Studies 34 (1): 1-34.

1999. Foreign direct investment-led growth: Evidence from time series and panel data. Oxford Economic Papers 51:133-51.

Dobson, Wendy, and Chia Siow Yue, eds. 1997. Multinationals and East Asian integration. Ottawa, Canada: International Development Research Centre.

Doms, Mark E., and J. Bradford Jensen. 1998. Comparing wages, skills, and productivity between domestically and foreign-owned manufacturing establishments in the United States. In Geography and ownership as bases for economic accounting, ed. Robert E. Baldwin, Robert E. Lipsey, and J. David Richardson, 235-58. Vol. 59 of Studies in income and wealth. Chicago: University of Chicago Press.

Driffield, Nigel. 2001. The impact on domestic productivity of inward investment in the U.K. The Manchester School 69 (1): 103-19.

Driffield, Nigel, and Sourafel Girma. 2003. Regional foreign direct investment and wage spillovers: Plant-level evidence from the electronics industry. Oxford Bulletin of Economics and Statistics 65:453-474.

Dunning, John H. 1958. American investment in British manufacturing industry. London: George Allen \& Unwin.

1970. The effects of United States direct investment on British technology. In Studies in international investment, ed. John H. Dunning, 345-400. London: George Allen \& Unwin.

Erdilek, Asim. 2002. Productivity and spillover effects of foreign direct investment 
in Turkish manufacturing: A plant-level panel data analysis. Case Western Reserve University, Department of Economics. (Processed).

Feenstra, Robert C., and Gordon H. Hanson. 1997. Foreign direct investment and relative wages: Evidence from Mexico's maquiladoras. Journal of International Economics 42 (3-4): 371-94.

Feliciano, Zadia, and Robert E. Lipsey. 1999. Foreign ownership and wages in the United States, 1987-1992. NBER Working Paper no. 6923. Cambridge, Mass.: National Bureau of Economic Research, January.

Figlio, David N., and Bruce A. Blonigen. 2000. The effects of foreign direct investment on local communities. Journal of Urban Economics 48 (2): 338-63.

Findlay, Ronald. 1978. Relative backwardness, direct foreign investment, and the transfer of technology: A simple dynamic model. Quarterly Journal of Economics 92 (1): 1-16.

Fontagné, Lionel, and Michaël Pajot. 2002. Relationships between trade and FDI flows within two panels of U.S. and French industries. In Multinational firms and impacts on employment, trade, and technology, ed. Robert E. Lipsey and JeanLouis Mucchielli, 43-83. London: Routledge.

Frank, Robert F., and Richard T. Freeman. 1975. Multinational corporations and domestic employment. Cornell University, Department of Economics. (Processed).

Girma, Sourafel, David Greenaway, and Katherine Wakelin. 2001. Who benefits from foreign direct investment in the U.K.? Scottish Journal of Political Economy 48 (2): 119-33.

Girma, Sourafel, and Katherine Wakelin. 2000. Are there regional spillovers from FDI in the U.K.? Centre for Research on Globalisation and Labour Markets Research Paper no. 2000/16. Nottingham, U.K.: University of Nottingham.

Globerman, Steven. 1979. Foreign direct investment and "spillover" efficiency benefits in Canadian manufacturing industries. Canadian Journal of Economics 12 (1): $42-56$.

Globerman, Steven, John Ries, and Ilan Vertinsky. 1994. The economic performance of foreign affiliates in Canada. Canadian Journal of Economics 27 (1): $143-56$.

Goldsmith, Raymond W. 1969. Financial structure and development. New Haven: Yale University Press.

Görg, Holger, and David Greenaway. 2001. Foreign direct investment and intraindustry spillovers: A review of the literature. Globalisation and Labour Markets Programme Research Paper no. 2001/37. Nottingham, U.K.: Leverhulme Centre for Research on Globalisation and Economic Policy.

Görg, Holger, and Eric Strobl. 2000. Multinational companies, technology spillovers, and firm survival: Evidence from Irish manufacturing. Centre for Research on Globalisation and Labour Markets Research Paper no. 2000/12. Nottingham, U.K.: University of Nottingham.

- 2001. Multinational companies and productivity spillovers: A metaanalysis. Economic Journal 111 (475): F723-F739.

2002. Multinational companies and indigenous development: An empirical analysis. European Economic Review 46 (7): 1305-22.

Griffith, Rachel. 1999. Using the ARD establishment-level data to look at foreign ownership and productivity in the United Kingdom. Economic Journal 109 (456): 416-42.

Griffith, Rachel, and Helen Simpson. 2001. Characteristics of foreign-owned firms in British manufacturing. Institute for Fiscal Studies Working Paper no. 01/10. London: Institute for Fiscal Studies. 
Haddad, Mona, and Ann Harrison. 1993. Are there positive spillovers from direct foreign investment? Journal of Development Economics 42 (1): 51-74.

Harris, Richard, and Catherine Robinson. 2002. The effect of foreign acquisitions on total factor productivity: Plant-level evidence from U.K. manufacturing, 1987-1992. Review of Economics and Statistics 84 (3): 562-68.

Harrison, Ann. 1996. Determinants and effects of direct foreign investment in Côte d'Ivoire, Morocco, and Venezuela. In Industrial evolution in developing countries, ed. Mark J. Roberts and James R. Tybout, 163-86. New York: Oxford University Press.

Haskel, Jonathan E., Sonia C. Pereira, and Matthew J. Slaughter. 2002. Does inward foreign direct investment boost the productivity of domestic firms? NBER Working Paper no. 8724. Cambridge, Mass.: National Bureau of Economic Research, January.

Head, Keith, and John Ries. 2002. Offshore production and skill upgrading by Japanese manufacturing firms. Journal of International Economics 58 (1): 81105.

Hill, Hal. 1990. Indonesia's industrial transformation, part II. Bulletin of Indonesian Economic Studies 26:75-109.

Howenstine, Ned G., and William J. Zeile. 1994. Characteristics of foreign-owned U.S. manufacturing establishments. Survey of Current Business 74 (1): 34-59.

Hufbauer, Gary C., and F. M. Adler. 1968. Overseas manufacturing investment and the balance of payments. Tax Policy Research Study no. 1. Washington, D.C.: Department of the Treasury.

Hymer, Stephen H. 1960. The international operations of national firms: A study of direct foreign investment. Ph.D. Diss. MIT, Department of Economics.

Imbriani, C., and F. Reganati. 1997. Spillovers internazionale di efficienza nel settore manifatturiero Italiano (International productivity spillovers in the Italian manufacturing sector). Economia Internazionale 50 (4): 583-95.

Kathuria, Vinish. 2000. Productivity spillovers from technology transfer to Indian manufacturing firms. Journal of International Development 12 (3): 343-69.

Kindleberger, Charles P. 1969. American business abroad: Six lectures on direct investment. New Haven, Conn.: Yale University Press.

Kokko, Ari. 1994. Technology, market characteristics, and spillovers. Journal of Development Economics 43 (2): 279-93.

- 1996. Productivity spillovers from competition between local firms and foreign affiliates. Journal of International Development 8 (4): 517-30.

Kokko, Ari, Mario Zejan, and Ruben Tansini. 2001. Trade regimes and spillover effects of FDI: Evidence from Uruguay. Weltwirtschaftliches Archiv 137 (1): 12449.

Kravis, Irving B., and Robert E. Lipsey. 1988. The effects of multinational firms' foreign operations on their domestic employment. NBER Working Paper no. 2760. Cambridge, Mass.: National Bureau of Economic Research, December.

Lewis, Arthur. 1954. Economic development with unlimited supplies of labour. Manchester School 22 (2): 139-91.

Lewis, Cleona. 1938. America's stake in international investments. Washington, D.C.: Brookings Institution.

Lipsey, Robert E. 1994. Foreign-owned firms and U.S. wages. NBER Working Paper no. 4927. Cambridge, Mass.: National Bureau of Economic Research, November.

1995. Outward direct investment and the U.S. economy. In The effects of taxation on multinational corporations, ed. Martin Feldstein, James R. Hines Jr., and R. Glenn Hubbard, 7-41. Chicago: University of Chicago Press. 
1998. Trade and production networks of U.S. MNEs and exports by their Asian affiliates. In Globalization, trade, and foreign direct investment, ed. John $\mathrm{H}$. Dunning, 204-16. Oxford: Elsevier Science, Ltd.

2000. Affiliates of U.S. and Japanese multinationals in East Asian production and trade. In The role of foreign direct investment in East Asian development and trade, ed. Takatoshi Ito and Anne O. Krueger, 147-90. Vol. 9 of NBER East Asian Seminar on Economics. Chicago: University of Chicago Press.

2002. Foreign production by U.S. firms and parent firm employment. In Multinational firms and impacts on employment, trade, and technology: New perspectives for a new century, ed. Robert E. Lipsey and Jean-Louis Mucchielli, 323. London: Routledge.

. 2003. Foreign direct investment and the operations of multinational firms: Concepts, history, and data. In Handbook of international trade, ed. E. Kwan Choi and James Harrigan, 287-319. London: Blackwell.

Lipsey, Robert E., Irving B. Kravis, and Romualdo A. Roldan. 1982. Do multinational firms adapt factor proportions to relative factor prices? In Trade and employment in developing countries: 2. Factor supply and substitution, ed. Anne O. Krueger, 215-55. Chicago: University of Chicago Press.

Lipsey, Robert E., and Eric Ramstetter. 2003. Japanese exports, MNC affiliates, and rivalry for export markets. Journal of the Japanese and International Economies 17 (2): 101-17.

Lipsey, Robert E., Eric Ramstetter, and Magnus Blomström. 1999. Parent exports and affiliate activity in Japanese multinational companies, 1986, 1989, 1992. In Analytical research based on data from the survey of overseas business activities, survey research on harmonizing globalization based on the 1997 survey of overseas business activities, 93-146. Tokyo: Institute for International Trade and Investment.

2000. Outward FDI and parent exports and employment: Japan, the United States, and Sweden. Global Economic Quarterly 1 (4): 285-302.

Lipsey, Robert E., and Fredrik Sjöholm. 2003. Foreign direct investment, education, and wages in Indonesian manufacturing. Journal of Development Economics, forthcoming.

Lipsey, Robert E., and Merle Yahr Weiss. 1981. Foreign production and exports in manufacturing industries. Review of Economics and Statistics 63 (4): 488-94.

. 1984. Foreign production and exports of individual firms. Review of Economics and Statistics 66 (2): 304-08.

Liu, Xiaming, Chengang Wang, and Yingqi Wei. 2001. Causal links between foreign direct investment and trade in China. China Economic Review 12 (2-3): 190202.

Madden, John T., Marcus Nadler, and Harry C. Sauvain. 1937. America's experience as a creditor nation. New York: Prentice Hall.

Manning, Chris. 1998. Indonesian labour in transition: An East Asian success story? Cambridge: Cambridge University Press.

Markusen, James R. 1997. Trade versus investment liberalization. NBER Working Paper no. 6231. Cambridge, Mass.: National Bureau of Economic Research, October.

Markusen, James R., and Keith E. Maskus. 2001. General-equilibrium approaches to the multinational firm: A review of theory and evidence. NBER Working Paper no. 8334. Cambridge, Mass.: National Bureau of Economic Research, June.

Moran, Theodore H. 2002. Beyond sweatshops: Foreign direct investment and globalization in developing countries. Washington, D.C.: Brookings.

Nadiri. 1992. U.S. direct investment and the production structure of the manufac- 
turing sector in France, Germany, Japan, and the U.K. New York University. Manuscript.

Oguchi, Noriyoshi, Nor Aini Mohd Amdzah, Zainon Bakar, Ravzah Zainal Abidin, and Mazlina Shafii. 2002. Productivity of foreign and domestic firms in the Malaysian manufacturing industry. Asian Economic Journal 16 (3): 215-28.

Okamoto, Yumiko, and Fredrik Sjöholm. 1999. FDI and the dynamics of productivity: Microeconomic evidence. Working Paper Series in Economics and Finance no. 348. Stockholm, Sweden: Stockholm School of Economics, December.

Oulton, Nicholas. 2001. Why do foreign-owned firms in the U.K. have higher labour productivity? In Inward investment, technological change, and growth, ed. Nigel Pain, 122-61. New York: Palgrave.

Pain, Nigel, ed. 2001. Inward investment, technological change, and growth. New York: Palgrave.

Ramstetter, Eric D. 1999. Comparisons of foreign multinationals and local firms in Asian manufacturing over time. Asian Economic Journal 13 (2): 163-203.

Reddaway, W. B., in collaboration with J. O. N. Perkins, S. J. Potter, and C. T. Taylor. 1967. Effects of U.K. direct investment overseas: An interim report. Cambridge University, Department of Applied Economics. Occasional Paper no. 12.

Reddaway, W. B., S. J. Potter, and C. T. Taylor. 1968. Effects of U.K. direct investment overseas: Final report. Cambridge University, Department of Applied Economics. Occasional Paper no. 15.

Rhee, Yung Whee, and Therese Belot. 1990. Export catalysts in low-income countries. World Bank Discussion Paper no. 72. Washington, D.C.: World Bank.

Rippy, J. Fred. 1931. The capitalists and Colombia. New York: Vanguard Press.

Romer, Paul M. 1993a. Idea gaps and object gaps in economic development. Journal of Monetary Economics 32 (3): 543-73.

1993b. Two strategies for economic development: Using ideas and producing ideas. In Proceedings of the World Bank annual conference on development economics, 1992, ed. Lawrence H. Summers and Shekhar Shah, 63-91. Washington, D.C.: World Bank.

Ruane, Frances, and Holger Görg. 1999. Irish FDI policy and investment from the EU. In Innovation, investment, and the diffusion of technology in Europe, ed. Ray Barrell and Nigel Pain, 44-67. Cambridge: Cambridge University Press.

Singh, Jasjit. 2002. Knowledge diffusion and the role of multinational subsidiaries: Evidence using patent citation data. Boston: Harvard Business School, October. (Processed).

Sjöholm, Fredrik. 1999. Technology gap, competition, and spillovers from foreign direct investment: Evidence from establishment data. Journal of Development Studies 36 (1): 53-73.

Slaughter, Matthew J. 2000. Production transfer within multinational enterprises and American wages. Journal of International Economics 50 (2): 449-72.

Smarzynska, Beata K. 2002. Does foreign investment increase the productivity of domestic firms? In search of spillovers through backward linkages. Washington, D.C.: World Bank. (Processed).

Sousa, Nuno, David Greenaway, and Katherine Wakelin. 2000. Multinationals and export spillovers. Centre for Research on Globalisation and Labour Markets. Research Paper no. 2000/14. London: University of Mottingham, School of Economics.

Swedenborg, Birgitta. 1973. Den Svenska industrins investeringar $i$ utlandet (Swedish industries' investment in foreign countries). Stockholm: Industriens Utredningsinstitut. 
1979. The multinational operations of Swedish firms: An analysis of determinants and effects. Stockholm: Industriens Utredningsinstitut.

1982. Svensk Industri I Utlandet. En Analys av Drivkrafter och Effekter. Stockholm: Industriens Utredningsinstitut.

1985. Sweden. In Multinational enterprises, economic structure, and international competitiveness, ed. John Dunning, 217-48. London: Wiley.

2001. Determinants and effects of multinational growth: The Swedish case revisited. In Topics in empirical international economics, ed. Magnus Blomström and Linda S. Goldberg, 99-131. Chicago: University of Chicago Press.

Swedenborg, Birgitta, Goran Johansson-Grahn, and Mats Kinnwall. 1988. Den Svenska industrins utlandsinvesteringar, 1960-1986 (Swedish industries' foreign investment, 1960-1986). Stockholm: Industriens Utredningsinstitut.

United Nations. 2000. World investment report, 2000: Cross-border mergers and acquisitions and development. Geneva: United Nations Conference on Trade and Development (UNCTAD).

. 2001. Measures of the transnationalization of economic activity. Geneva: United Nations Conference on Trade and Development (UNCTAD).

Wang, J. Y., and Magnus Blomström. 1992. Foreign investment and technology transfer: A simple model. European Economic Review 36 (1): 137-55.

Wheeler, David, and Ashoka Mody. 1992. International investment location decisions: The case of U.S. firms. Journal of International Economics 33 (1-2): 57-76.

Wilkins, Mira. 1989. The history of foreign investment in the United States to 1914. Cambridge: Harvard University Press.

World Bank. 1987. Trade policy and industrialization. World development report, 1987, 78-94. New York: Oxford University Press.

World Economic Forum. 2002. Global competitiveness report, 2001-2002. Geneva: World Economic Forum.

\section{Comment Vanessa Strauss Kahn}

Robert Lipsey's paper surveys the existing literature on foreign direct investment (FDI) in an attempt to elucidate the effects of multinational activity on the home and host countries. Based on a comprehensive review of mostly empirical papers, the paper summarizes the effects of FDI on exports and factor demand in the home country and on wages, productivity, and growth in the host country.

Robert Lipsey's expertise in the field of FDI and his extensive knowledge of the literature show in the paper. I find myself almost wholly in agreement with the author, also partly, perhaps, because he so graciously took account of comments I had made on the first draft of this paper. Hence, my comments are few and mainly consist on suggestions for further developments.

First, I think that further distinctions could be made between cost- 
oriented FDI and FDI that aims at accessing a market. While I would agree with Lipsey that such a distinction is not always straightforward, some FDI activities clearly aim at reducing production costs by locating plants abroad. ${ }^{1}$ In such cases, most of the local production is exported to the multinational enterprise's (MNE's) parent in the home country or to a third country for final consumption. Distinguishing the type of FDI is important because the effects of FDI on the home and the host countries may differ accordingly. If the internationalization of production follows countries' comparative advantage, MNEs will tend to relocate plants of production in which the home country is relatively less efficient to foreign countries. Such relocation of production may not have negative effects on average wages and employment levels in the home country. However, it may have important distributional effects among home-country workers, because changes in labor demand likely affect wages and employment of the less-skilled workers more than their skilled counterparts.

I also believe that the paper should further distinguish FDI effects on developed and developing countries. For instance, most studies concluded that foreign-owned firms pay higher wages than their domestically owned counterparts. Reducing worker turnover and attracting better workers are worldwide explanations of such features. However, compensating for home-biased preferences seems to be a consideration more specifically adapted to inward FDI in a developed country. In developing countries other explanations (e.g., closing wage gaps between the multinational entities) may lead to this wage differential. Similarly, there is strong evidence that foreign-owned plants have higher productivity than domestically owned ones. The higher efficiency of foreign-owned firms in developing countries is predictable, as foreign-owned plants are likely to use more capital and/or more advanced production and managerial organization techniques. Two main reasons induce the higher productivity of foreign-owned plants in developed countries. First, there may be a selection bias as firms investing in multinational activities could likely be the most productive in the first place. Second, most FDI occurred through ownership consolidation, which usually leads to higher efficiency through firms' restructuring. Empirical studies aiming at estimating the productivity of foreign-owned firms relative to their domestically owned counterparts should hence control for efficiency gains from national firms' consolidation. As mentioned by Lipsey, one study by Harris and Robinson (2002) goes in that direction. It concludes that plant turnover seems to involve relatively more productive plants. I would encourage further research on that issue.

More importantly, I believe that future empirical studies on multinational activity and its effects on home and host countries should make use of micro-level data. For example, most empirical studies focusing on the 
effects of outward FDI on the home country concluded that exports and production abroad were, for the most part, complementary. Such a result is surprising, as standard theory of MNEs would assume both substitution and complementarity effects (see, e.g., Rob and Vettas 2003). Most studies, however, analyze the relationship between FDI and one of the following home-country variables: country exports, industry exports, or, in the best cases, firms' exports. While these results are important, they do not exclude the possibility that substitution arises when one looks at more disaggregated data levels. For example, if an MNE exports intermediate goods to its foreign assembly line, it induces complementarity between exports and foreign production at the industry or the firm level. However, at the product level (i.e., the final good), foreign production substitutes for exports. Notably, Blonigen (2001) uses product-level data and finds substantial evidence for both substitution and complementarity between foreign production and exports.

Studying micro-level data could also improve the current knowledge on the effect of FDI on wages and employment. If the labor mix (skilled to unskilled workers) were similar across products, using disaggregated data would not add significance to firm-level or industry-level data. However, if the labor mix varies across products with, say, a higher employment share of skilled workers in the production of parts and components than in assembly line, then increased FDI may have a significant impact on wage dispersion. Feenstra and Hanson (1999) use detailed data on imported inputs to assess the effect of outsourcing on the relative wage of skilled to unskilled workers. They find that outsourcing explains at least 15 percent of the U.S. wage-premium increase (this number may reach 40 percent in certain specifications). Although their research does not focus on FDI per se, as it also encompasses arm's-length production, I believe that their analysis sheds light on the effects of FDI on wage dispersion. Similarly, and as mentioned in the paper, Head and Ries (2002) find that affiliate employment does not affect the share of unskilled workers' wage in the total wage bill in the home country when they use industry-level data. In contrast, when they use firm-level data, they find that there is substitution between home and foreign activities of the firms toward a lower share of unskilled workers' wage in the total wage bill in the home country.

Should countries promote or discourage FDI, or leave it to market forces? As Lipsey put it in the introduction of the paper, these are important policy issues. They might be even more so for developing countries in search of a high positive-growth path. While most of the literature has been not conclusive as to the direction of wage and productivity spillovers, there is strong evidence that FDI raises the average level of wages in the host country and that foreign-owned firms have higher productivity levels than domestically owned ones. Are these features convincing enough to support costly FDI promotion policies (e.g., tax rebates or reduced tariffs on im- 
ports)? I believe that further research should focus on identifying the necessary conditions for successful FDI. While there seems to be no clear-cut answer for this question, one could attempt to define industries in which technological spillovers are positive, and identify countries' characteristics that help enhance such spillovers (education is a likely candidate). Among such sector-specific studies I believe that the issue of spillovers to suppliers has received too little attention. Apart from two unpublished papers by Aitken and Harrison (1991) and Smarzynska (2002), this area of research indeed lacks evidence. Finally, it could be interesting to obtain some empirical evidence on the potential effect of inward FDI on host-country industrial agglomeration. More specifically, one could wonder whether the establishment of foreign-owned firms in a country leads to industrial clusters, by attracting upstream and downstream activities in that location.

\section{References}

Aitken, B., and A. Harrison. 1991. Are there spillovers from foreign direct investment? Evidence from panel data for Venezuela. Processed, MIT and the World Bank, November.

Bloningen, B. 2001. In search of substitution between foreign production and exports. Journal of International Economics 53:81-104.

Feenstra, R., and G. Hanson. 1999. The impact of outsourcing and hightechnology capital on wages: Estimates for the United States, 1979-1990. Quarterly Journal of Economics 114 (3): 907-940.

Harris, R., and C. Robinson. 2002. The effect of foreign acquisitions on total factor productivity: Plant-level evidence from U.K. manufacturing, 1987-1992. Review of Economics and Statistics 84:562-568.

Head, K., and J. Ries. 2002. Offshore production and skill upgrading by Japanese manufacturing firms. Journal of International Economics 58:81-103.

Rob, R., and N. Vettas. 2003. Foreign direct investment and exports with growing demand. Review of Economics Studies, forthcoming.

Smarzynska, B. 2002. Does foreign investment increase the productivity of domestic firms? In search of spillovers through backward linkages. World Bank Research Working Paper no. 2923. Washington, D.C.: World Bank. 